\title{
Dulcor misericordiae. Justicia y misericordia en el ejercicio de la autoridad canónica. I. Historia
}

\author{
Dulcor misericordiae. Justice and Mercy in the Exercise \\ of Canonical Authority. I. History
}

\section{Javier OTADUY}

Profesor Ordinario de Parte general y Derecho de la persona Facultad de Derecho Canónico. Universidad de Navarra jotaduy@unav.es

Resumen: En los orígenes del derecho canónico hubo una necesidad específica de la intervención equitativa por razones más o menos ocasionales. La equidad canónica se fue perfilando en dos direcciones, como perfecta justicia y como intervención benigna. Estas «dos almas» han permanecido siempre. Absorbe también a la epiqueya, cuando la generalidad propia de la ley provoca una deficiencia para la valoración de un caso singular. Para entender bien la doctrina canónica medieval sobre la aequitas se estudian tres sucesos representativos que han dado ocasión a la doctrina canónica de verter sus comentarios sobre la aequitas: una epístola de san Agustín contenida en el Decreto de Graciano; un pasaje de una decretal de Honorio III recogida en el Liber Extra; y el debate entre Martín de Gosia y Búlgaro. Con ocasión de ello se extraen algunas conclusiones sobre el valor permanente de la equidad y algunas reglas hermenéuticas sobre su uso.

Palabras clave: Justicia, Misericordia, Aequitas canonica.
Abstract: In the early stages of canon law there was a specific need to intervene to ensure equity in given situations. Canonical equity began to take two forms: perfect justice and benign intervention. These two «souls» have coexisted since the start. Equity encompasses epikeia when the general nature of the law prevents the just appraisal of a specific case. Three representative cases are considered to provide a clearer understanding of the medieval canonical doctrine on aequitas: a letter by St. Augustine in the Decretum Gratiani; a passage from a decretal by Honorius III contained in the Liber Extra; and the great debate between Martinus Gosia and Bulgarus. A number of conclusions as to the ongoing value of equity and some hermeneutical rules relating to its application are drawn on the basis of this discussion.

Keywords: Justice, Mercy, Aequitas canonica. 
ए 1 año de la misericordia, en el que se publican estas páginas (2016), ha convocado a muchos canonistas a escribir sobre la relación entre misericordia y justicia. Hay mucho que decir, y yo querría dividir en dos mi aportación. Esta primera parte revisa la historia, es decir, el modo como ha gestionado y comprendido la Iglesia su propia vida. Porque en el fondo, hablar de justicia y misericordia, hablar de equidad, quiere decir presentar las soluciones que la Iglesia ha diseñado para las vicisitudes de su caminar terreno. En un artículo próximo (que será la continuación de éste) presentaré la cuestión tal y como se plantea hoy.

\section{El PELIGRO DE los BinOMios ALTERNATIVOS O DiALÉCTICOS}

Hay un modo frecuente de describir el derecho canónico a través de binomios contrapuestos. Una de las versiones sería precisamente la de justicia y misericordia. En realidad, más aún que para el derecho canónico, se acostumbra a emplear este sistema del doble valor contradictorio para describir la misma realidad eclesial. La Iglesia de la justicia sería la Iglesia del derecho, de la ley, de la letra, de la jerarquía, de la institución, del poder, de la organización. La Iglesia de la misericordia sería la Iglesia de la caridad, del espíritu, del carisma, de la libertad, de la vida, del acontecimiento. Claro está que no todas estas cosas quieren decir lo mismo. Pero hay una matriz común en esta tensión dialéctica. Siempre que se emplea el binomio se quiere subrayar que la preeminencia de actividad y de valor pertenece a la caridad-misericordiaEspíritu, mientras que a la justicia-derecho-poder le corresponde un valor pasivo y secundario. Simultáneamente se quiere decir también que los valores jurídicos (según esta versión secundarios) son arrastrados en la vida de la Iglesia como algo inevitable de su condición histórica, como un mal necesario, y deben ser siempre interpelados y denunciados por el oficio profético del otro platillo de la balanza, que es el espíritu de caridad y de misericordia.

Pero no puede existir una verdadera relación dialéctica de opuestos entre estas realidades. Eso es inútil, pero sobre todo es falso. Toda visión dialéctica o simplemente de contraste tiene una indudable falsedad teológica, que ha recibido condenas de gran densidad magisterial, desde Juan XXII en el siglo catorce ${ }^{1}$ hasta el n. 8 de Lumen Gentium, que se expresa así: «La sociedad pro-

1 «Así, pues, el primer error que sale de la tenebrosa oficina de esos hombres, fantasea dos Iglesias, una carnal, repleta de riquezas, que nada en placeres, manchada de crímenes, sobre la que afirman dominar el Romano Pontífice y los otros prelados inferiores; otra espiritual, limpia por su sobriedad, hermosa por la virtud, ceñida de pobreza, en la que se hallan ellos solos y sus cómplices, y 
vista de sus órganos jerárquicos y el Cuerpo místico de Cristo, la asamblea visible y la comunidad espiritual, la Iglesia terrestre y la Iglesia enriquecida con los bienes celestiales, no deben ser consideradas como dos cosas distintas, sino que más bien forman una realidad compleja que está integrada de un elemento humano y otro divino. Por eso se la compara, por una notable analogía, con el misterio del Verbo encarnado, pues así como la naturaleza asumida sirve al Verbo divino como de instrumento vivo de salvación unido indisolublemente a Él, de modo semejante la articulación social de la Iglesia sirve al Espíritu Santo, que la vivifica, para el acrecentamiento de su cuerpo (cfr. Ef 4,16)».

Nadie puede afirmar, si verdaderamente quiere ser católico, que existen dos Iglesias, ni siquiera dos vértices antagónicos de una Iglesia. Cristo es uno, la Iglesia es una. Su humanidad es instrumento de su divinidad y trámite imprescindible para la acción del Espíritu. En cualquier caso debe quedar claro desde el principio que la relación entre justicia y misericordia no es una relación de opuestos (iustitia versus misericordia) ni de alternancias (aut iustitia aut misericordia). Es un binomio de máximos. Hay que ser justos, hay que ser misericordiosos. No es buena táctica elegir entre la justicia y la misericordia, y además se entienden muy mal por separado.

\section{RAZONES DE LA PRESENCIA DE LA MISERICORDIA Y DE LA EQUIDAD EN LOS ORÍGENES DEL DERECHO CANÓNICO}

Exacerbar las diferencias podría hacer pensar que no cabe una versión complementaria de la justicia y la caridad en el ordenamiento canónico. Pero indudablemente cabe, es más, están una y otra reclamadas recíprocamente. El papa Francisco lo ha recordado en la bula de convocatoria del jubileo de la misericordia: «No será inútil en este contexto recordar la relación existente entre justicia y misericordia. No son dos momentos contrastantes entre sí, sino un solo momento que se desarrolla progresivamente hasta alcanzar su ápice en la plenitud del amor» ${ }^{2}$. Para entenderlo es necesario captar y matizar bien el papel que juegan una y otra ${ }^{3}$.

\footnotetext{
sobre la que ellos también mandan por merecimiento de la vida espiritual, si es que hay que dar alguna fe a sus mentiras» (JuAN XXII, Bula Gloriosam Ecclesiam [26-I-1318] 14 [Dz-Hün 911]).

2 FrancIsCO, Bula Misericordiae vultus, 11-IV-2015, n. 20.

${ }^{3}$ Muy útiles para entender esta relación en el ámbito de la culpa y el perdón de la culpa, tanto en la sagrada Escritura como en la filosofía contemporánea de raíz cristiana, son los trabajos de C. Granados, Misericordia y alianza en Ex 34,6-7, Scripta Theologica 48/1 (2016) 99-111; y R. MUÑZ, Fusticia y misericordia. Culpa, punición y perdón, Scripta Theologica 48/1 (2016) 131-148.
} 
El derecho canónico hizo comparecer la misericordia en su ámbito por una cuestión de autenticidad. Formaba parte de la revelación cristiana, y no precisamente como una cuestión menor. No puede haber una autoridad canónica que no ame y que no ejercite la misericordia. En esto el Prólogo de Ivo de Chartres a su Decreto ${ }^{4}$ es un modelo. Según Ivo, la caritas es maestra en el camino del derecho y a su vez el derecho conduce a la plenitudo caritatis. Por tanto, el amor y la misericordia están al comienzo, en el medio, y al final ${ }^{5}$. Algo semejante podríamos decir del Liber de misericordia et iustitia de Algerio de Lieja ${ }^{6}$, seguidor de Ivo. Y por supuesto de Graciano, que compone su Decreto inmediatamente después y en cierto modo siguiendo los pasos de estos precursores.

Pero además de esa primera razón (es decir, de mera autenticidad cristiana) que hace incontestable la presencia de la misericordia en el derecho canónico, hay otras tres, mucho más circunstanciales pero igualmente efectivas. Una de esas razones tiene que ver con los primeros pasos del derecho canónico científico. Son unos pasos de concordancia. Se quiere conseguir que aquello que es disonante, consuene, se armonice. Habían pasado muchos siglos

${ }^{4}$ El prólogo fue una obra previa, De consonantia canonum, escrito como se ve con criterios muy parecidos a la Concordia discordantium canonum de Graciano. Después pasó a convertirse en el Prólogo del Decreto de Ivo, y como tal fue una obra difundidísima.

5 Cfr. Ivo de Chartres, Prólogo, en B. Bransington, «Require in Prologo». The Decretists and Ivo of Chartres' Prologue, Zeitschrift der Savigny-Stiftung für Rechtsgeschichte, kan. Abt. 118 (2001) 84-124. Para un tratamiento interesante de misericordia y justicia en Ivo, cfr. O. CondorelLI, Carità e Diritto agli albori della scienza giuridica medievale, en J. MiÑambres (a cura di), Diritto canonico e servizio della carità, Giuffrè, Milano 2008, 44-51.

${ }^{6}$ Cfr. R. KretzSChMAR, Alger von Lüttichs Traktat «De misericordia et iustitia». Ein kanonistischer Konkordanzversuch aus der Zeit des Investiturstreits, Jan Thorbecke, Sigmaringen 1985, 158-180. Sobre el contenido de la obra valgan estas palabras: «Como los malvados desconocen u olvidan los preceptos canónicos y los simples no los comprenden, Algerio se propone exponer y aclarar su contenido para que "discretione veritatis bonorum adiuvaretur devotio et canonice auctoritatis evidentia perversorum vinceretur contentio". Las distinciones misericordia-justitia y contrarietas-diversitas orientan la interpretación de las autoridades. El tratado se divide en tres partes. La primera se ocupa de la gracia (misericordia) y muestra "quomodo vel quamdiu tolerandis malis": sublimidad de la misericordia respecto a la justicia, atenuación y dispensa de los preceptos canónicos, justo castigo para quienes no se corrigen por la misericordia, modo de tratar a los indignos, corrección de los superiores por sus súbditos, ámbito y límites de la tolerancia, valor de los sacramentos administrados por los ministros indignos, oportunidad y conveniencia de la corrección. La segunda parte explica cuándo y cómo se ha de ejercer la justicia (“[...] superius de malorum tolerantia [...] nunc de eorundem disciplina canonice exercenda, quis modis discretionis vel ordinis adhibendus sit [...]”): aspectos que se deben tener en cuenta al aplicar la disciplina eclesiástica, acusación de los superiores por sus súbditos, infamia, legitimidad de los acusadores, restitución de las dignidades a los arrepentidos, procedimiento y desarrollo del juicio sinodal. Por último, la tercera parte trata "de variis heresibus" ("de his qui extra ecclesiam sunt"): sacramentos administrados por cismáticos y herejes, y de la simonía» (J. M. VIEJO-XIMÉNEZ, «Algerio de Lieja», DGDC I, 291). 
de almacenamiento no sistemático de textos que contenían decisiones pastorales de alcance muy distinto. En esta tarea de consonancia era necesario resolver constantemente pequeños encontronazos entre decisiones rigurosas y decisiones benignas. Un asunto idéntico o análogo había sido resuelto en la historia de modos muy distintos. Dice Martin Brett, tratando del Prólogo de Ivo de Chartres: «Allí donde los cánones a veces exigen rigor, otras veces permiten dispensa o relajación y eso debe explicarse en gran parte por las circunstancias en las que se tomó cada decisión. Los cánones deben aplicarse con severidad donde la enfermedad del pecado está muy enraizada y con menos rigor en el caso de los realmente arrepentidos que pueden recuperar la salud espiritual. Todos los casos deben juzgarse de acuerdo con el deber primordial de la caridad y la disposición interna del penitente» ${ }^{7}$. Gran parte de las reglas de Ivo, de Algerio, de Graciano, no son para decir que una decisión vale y la otra no, sino para decir cuándo hay que elegir el rigor, cuando la benignidad $^{8}$. Dicho de otra forma, no para elegir entre el ius y la misericordia, sino para elegir entre el ius más riguroso y el ius más benigno ${ }^{9}$. Cada texto refleja una toma de posición conciliar, pontificia o de los Padres que responde al rigor o a la moderatio que las circunstancias exigían ${ }^{10}$. Por otra parte, no todos los textos emplean el mismo lenguaje de obligación ni manifiestan el mismo grado de imperatividad ${ }^{11}$. Y por supuesto, en el caso de que se busque la

${ }^{7}$ M. BRETT, «Ivo de Chartres», DGDC IV, 851.

${ }^{8}$ Graciano por ejemplo presenta el texto de la solución benigna que para un caso determinado ofrece el papa Pelagio al obispo Florentino, permitiendo que se ordenase como diácono un viudo que había tenido después de la muerte de su mujer hijos con la sierva. El dictum gracianeo dice a continuación: «Hoc ex dispensatione misericordiae; ceterum ex rigore disciplinae intelligitur illud Aurilaniensis Concilii: [...] Si quis de laicis post uxorem suam aliam cuiuscumque conditionis cognoverit mulierem, in clerum nullatenus admittatur» (D. 34, cc. 7-8).

9 Opiniones de Esteban de Tournai y de Juan Teutónico optando por una solución legal en lugar de otra en virtud de la equidad benigna, presenta por ejemplo Ch. LEFEBVRE, Les pouvoirs du juge en droit canonique. Contribution bistorique et doctrinale à l'étude du canon 20 sur la méthode et les sources en droit positif, Sirey, París 1938, 181.

10 «Il lettore deve essere avvertito che la possibile, per non dire ricorrente, discordia tra i testi tramandati nelle collezioni canoniche può essere conciliata quando si tenga conto che essa è manifestazione della dialettica, interna al sistema giuridico, fra rigor e moderatio, fra iudicium e misericordia. Ivo individua le tre finalità (intenciones) della disciplina ecclesiastica nella distruzione del peccato, nel perdono, nell'edificazione del regno di Dio» (O. Condorelli, Carità e Diritto agli albori della scienza giuridica medievale..., cit., 45-46).

11 «Hoc attendens diligens lector intelleget unam esse faciem eloquiorum sacrorum, cum distincte considerabit quid sit ammonicio, quid sit preceptum, quid prohibicio, quid remissio et hec nec se invicem impugnare nec a se invicem distare, set omnibus sanitatis remedium pro sua moderatione dispensare» (Ivo DE Chartres, Prólogo, en B. BrANSINGTON, «Require in Prologo». The Decretists and Ivo of Chartres' Prologue..., cit., 118). 
moderación a través de la dispensa, habrá de tratarse de materias que pueden ser dispensadas ${ }^{12}$.

Veamos la tercera razón que explica el puesto de preeminencia de la misericordia en el origen del derecho canónico. Como ha dicho frecuentemente Onorato Bucci, el derecho canónico, así como el derecho de las ciudades y de los pequeños reinos, era considerado como una alternativa benigna, autónoma, equitativa, frente al rigor iuris de la tradición romanística imperial. «En defensa de las autonomías comunales estaba la autoridad pontificia y el jus canonicum que contraponía la aequitas al rigor iuris del derecho civil (entendido como lectura contemporánea del jus romanum) para tutelar la libertad de los entes menores e intermedios frente al Imperio, y por lo tanto contra los excesos del poder imperial. Y además era de derivación cristiana, contrariamente al derecho romano, que aunque llevase el "nomen Christi", era profundamente pagano» ${ }^{13}$. No se trata por tanto de rechazo del ius para

12 «Praecepciones itaque et prohibiciones alie sunt mobiles alie immobiles. Praecepciones immobiles sunt quas lex eterna sanxit, que observare salutem conferunt, non observate eandem auferunt, qualia sunt: "diliges Dominum Deum tuum ex toto corde tuo et proximum tuum sicut teipsum"; et "honora patrem et matrem" [Ex 20.12], et si qua sunt his similia. Mobiles vero sunt quas lex eterna non sanxit, set posteriorum diligencia racione utilitatis invenit non ad salutem principaliter obtienendam set ad eam tucius muniendam» (Ivo DE CharTres, Prólogo, en B. BRANSINGTON, «Require in Prologo». The Decretists and Ivo of Chartres' Prologue, cit., 120); «Quod tamen iam monuimus iterum monemus, ut si quis quod legerit de sanctionibus sive dispensationibus ecclesiasticis ad caritatem, que est plenitudo legis, referat, non errabit, non peccabit et quando aliqua probabili racione a summo rigore declinabit caritas excusabit, si tamen nichil contra evangelium, nichil contra apostolos usurpaverit» (ibid., 141).

${ }^{13}$ La traducción al castellano de este texto y de otros latinos y de lenguas modernas son míos. El conjunto del pasaje de Bucci dice así: «I giureconsulti insegnavano nei Centri Universitari della Penisola, in primo luogo Bologna, a difesa delle posizioni dell'Impero e proclamavano le loro verità con il rigor iuris imponendo lo ius civile che altro non era che la lettura contemporanea del diritto e della tradizione romanistica. Questo rigor iuris di derivazione romanistica era tutelato non solo dai giuristi delle Università del Nord e del Centro dell'Italia, ma anche dai giuristi della Scuola Napoletana che negavano la qualifica di ius proprium (perchè "ratione carens" e quindi "iniquum") al diritto longobardo. In entrambi i casi, sia per i giuristi della Scuola Bolognese sia per quelli della Scuola Napoletana, il diritto romano con il suo rigor iuris era a difesa dell'Impero, o comunque della concezione politica imperiale, dunque, del potere dello Stato verso le comunità minori, che a quel tempo altro non erano che le autonomie municipali che si esprimevano attraverso gli Statuti comunali. / A difesa delle autonomie comunali stava l'autorità pontificia e lo jus canonicum che contro il rigor iuris del diritto civile (inteso come lettura contemporanea dello jus romanum) contrapponeva l'aequitas che era a tutela della libertà degli enti minori e intermediari con l'Impero, e quindi contro lo strapotere imperiale. E che poi era di derivazione cristiana, contro un diritto romano che, pur portando il "nomen Christi", era profondamente pagano» (O. BuCCI, «Utrumque ius»: le ragioni del diritto nella storia della Chiesa, Institutum Theologicum Franciscanum, Roma 2002, 18). 
elegir la misericordia o la equidad, sino de elección del ius proprium frente al rigor iuris imperial o civil. Digamos que esta última razón tiene una importancia notable en la configuración de la aequitas canónica. Es canónica, desde luego, porque recibe el soplo de la misericordia revelada. Pero sobre todo se llama a sí misma canónica porque quiere distinguirse de una aplicación indiscriminada de los textos romanos. Esto es la Iglesia, no es el Estado, vienen a decir los grandes canonistas medievales. El canonista más significado en la construcción de la noción de equidad canónica fue el cardenal Hostiense. Lo que decía Enrique de Susa, como veremos, era que allá donde la legislación romana dificultaba soluciones jurídicas acordes con el espíritu cristiano o fomentaba la comisión de un pecado (por ejemplo porque permitía invalidar los juramentos o incumplir las promesas), allí la equidad canónica encontraba una solución de justicia propia. Siempre era misericordiosa, pero no siempre era más fácil. Ordinariamente era más exigente desde el punto de vista moral.

La última razón que traemos aquí es paradójica si la contemplamos en relación con la que acabamos de presentar. En efecto, la tradición jurídica romana podía contener ocasionalmente ciertos obstáculos para la aplicación del espíritu cristiano. Pero no hay que olvidar que antes que nada era una enorme potencia civilizadora. Era ratio. Frente a ella, el derecho de los pueblos bárbaros supone un doloroso empobrecimiento. $\mathrm{Y}$ la aequitas es con frecuencia reclamada por los juristas y por los ciudadanos cultos para oponerse al derecho de origen germánico. Todos los pueblos bárbaros tenían sus costumbres y su derecho, pero fueron sobre todo los longobardos por razones obvias de cercanía los que más tropezaron con los juristas de la península itálica. De esta manera, dice Francesco Calasso, «nació en aquel momento el problema de la aequitas; $\mathrm{y}$, como todos los grandes problemas cuando se hacen presentes a la conciencia por primera vez, no fue concebido en los términos en los que la doctrina lo discutirá algunos siglos más tarde, tecnificándolo y por la misma razón reduciéndolo, sino que afectó a las raíces más profundas del orden jurídico: precisamente por eso no es fácil caracterizarlo en sus orígenes. El origen fue precisamente el momento en que el invasor dictó sus leyes, y la civilización de los vencidos rechinó con el golpe como no lo había hecho nunca. ¿Aquello era derecho? Algunos siglos más tarde, el autor, atormentadísimo y cáustico, de las Quaestiones de iuris subtilitatibus, refiriéndose a los legisladores bárbaros con un desdén que todavía no se había aplacado, repetirá el ancestral desprecio del pueblo itálico por éstas así llamadas leyes: Recolunt tamen adbuc quidam 
buiusmodi suas, ut ipsi dicunt, "leges" ${ }^{14}$. Para luchar contra esta legislación que contenía no pocos aspectos irracionales para una mentalidad civilizada por el derecho civil ${ }^{15}$, los juristas opusieron la aequitas. Que no es simplemente, como repite sin cansancio Calasso, una técnica para interpretar la ley en caso de duda, para suplirla en caso de ausencia o para añadirle una cierta dosis de benignidad cuando ofrece una solución rigurosa. $\ll_{i}$ Una batalla así no se combatió por un canon hermenéutico!» ${ }^{16}$. Fue una batalla entre dos civilizaciones, entre dos universos jurídicos. $\mathrm{Y}$ en esa batalla la equidad fue invocada como razón, como naturaleza, como el mismo Dios. Aequitas, id est ratio, id est natura, id est Deus.

\section{ACTUALIDAD DE LA DOCTRINA CANÓNICA MEDIEVAL SOBRE LA AEQUITAS}

Pero todas estas razones son de los orígenes. Uno se podría preguntar qué significado tiene hoy el derecho canónico medieval. Estamos reclamados por cuestiones suscitadas ahora (como la comunión de los divorciados o el proceso abreviado de nulidad), muy lejos de las que tenían lugar entonces, y con unas claves doctrinales distintas. ¿A qué viene una fenomenología de hace diez siglos (o quince) y una teoría jurídica de entonces? Éste es un reproche posible, incluso comprensible, pero no es inteligente. Es cierto que estamos en otros tiempos pero no estamos en otra Iglesia, y aquí comparecerán muchas cuestiones que tienen que ver primariamente no con nuestros tiempos, sino con el diseño de Dios creador y redentor, tan actuales entonces como ahora. Pero sobre todo hay una segunda cuestión. El argumento de fondo que nos va a ocupar ha permanecido asentado en los fundamentos doctrinales que pusie-

${ }^{14}$ F. CALASSo, Introduzione al Diritto comune, Giuffrè, Milano 1970, 168 [traducción propia]. La cita es de Quaestiones de iuris subtilitatibus I, 16 (H. FiTTING [ed.], Berlín 1894, 56, cit. por F. CaLaSso, ibid.).

15 Hablando sobre el mundualdus, un derecho de propiedad, que admitía la ley longobarda, del marido sobre la mujer, Lucas de Penna alegaba la autoridad de Bartolomé de Capua y de Andrés de Isernia, con estas duras palabras: «utinam tale ius in exilium damnaretur, sicut venerandae memoriae dominus Bartholomeus de Capua prout audivi conatus fuit illud auferre; multi utuntur eo iure, alii vero non, sed in nonnulis civitatibus alii vivunt eo iure, alii vero illud abiiciunt. Ecce quanta est absurditas. Non sine ratione unde dominus Andreas de Isernia vocat leges illas ius asininum» (LuCas De Penna, Super tres Libros Codicis, X videlicet XI et XII, Pierre de Sartieres, París 1509 , lib. XII, tit. 35, lex 10, fol. 332v).

${ }^{16}$ F. Calasso, Introduzione al Diritto comune..., cit., 170. 
ron los primeros maestros. La aequitas canónica, o si se quiere las relaciones entre la justicia y la misericordia, está sustancialmente donde estaba.

La aequitas en efecto absorbe en el ámbito del derecho canónico el binomio justicia y misericordia. Hay una tendencia natural en todo canonista a recurrir a la equidad canónica para dar razón de las soluciones benignas del ordenamiento. Ya veremos que eso no es del todo exacto, pero no hay ningún inconveniente en aceptar que la equidad canónica contempla expresamente la benignidad y la misericordia. Por eso un estudio sobre la justicia y la misericordia en la actuación de la autoridad en la Iglesia es un estudio que remite a la equidad canónica. A partir de ahora obviaremos muchas veces la remisión a los dos términos del binomio y nos referiremos sencillamente a la equidad.

No tendría sentido que estudiáramos la aequitas canónica como si fuese una institución jurídica. La aequitas, como la justicia, no es una institución, es mucho más. Las instituciones canónicas son realidades sectoriales, ordinariamente nacidas del derecho positivo y conceptualizadas y sistematizadas después a partir de él. Los impedimentos matrimoniales, la parroquia o el proceso son instituciones canónicas. Todas las instituciones viven en un régimen jurídico determinado, régimen que cambia con el tiempo. Lógicamente no se puede hablar por ejemplo de las nociones de ley, de parroquia o de excomunión presentes en el Decreto de Graciano como si fueran las actuales, porque no lo son en absoluto. Sin embargo, la justicia y la equidad no son instituciones, son sustancia misma del derecho. No son sectoriales sino integradoras. Conforman el derecho positivo e influyen en él, pero no al modo de lo accesorio sino de lo sustancial. Se puede hablar de la aequitas del siglo XII como si fuera la nuestra porque lo es, no puede no serlo.

¿De verdad se puede dar por válida hoy la doctrina medieval sobre la aequitas? A mi juicio sí, aunque hay que adoptar algunos matices. Desde luego no es lo mismo equidad que doctrina canónica fraguada en torno a ella. Esa doctrina no tiene como función primaria decir qué es la equidad, sino establecer con qué reglas funciona en algunos supuestos (lo que Calasso llamaría el canon hermenéutico). En consecuencia se podría pensar que ya no estamos ante la sustancia del derecho, inmutable a través de las edades (la equidad como justicia perfecta atemperada por el amor cristiano), sino ante unas reglas históricas más o menos cambiantes y relativas.

¿Estamos pues ante unas reglas contingentes? Es cierto que son reglas, que no son definiciones ni absolutos jurídicos. Pero las reglas formuladas en los primeros siglos del derecho canónico sabio para formalizar la actividad 
equitativa no son reglas cualesquiera. Hoy habrá quien las discuta, pero en los últimos siete siglos no las ha discutido casi nadie. Son reglas que se establecen para proteger las fronteras más elementales de la prudencia, para mantener a salvo los valores primarios del derecho, o para no poner en riesgo el sistema jurídico. A mi juicio por tanto se puede decir que siguen valiendo. Eso no significa como es natural que todos los argumentos sobre la equidad se agotasen entonces. Lo que quiere decir es que los argumentos de entonces, en la medida en que la doctrina canónica los cribó y los aceptó, siguen siendo actuales.

\section{LA AEQUITAS ROMANA EN EL ORIGEN DE LA EQUIDAD CANÓNICA}

Se ha hecho común, desde que Pier Giovanni Caron publicó un libro con ese título ${ }^{17}$, decir que la aequitas canónica acoge en absorción sucesiva el concepto de aequitas romana, el de misericordia patrística y el de epiqueya aristotélica. En efecto, la equidad canónica se nutre del derecho romano como de su primera fuente.

El derecho romano va recibiendo el influjo de la equidad de una manera progresiva. El vocablo aequitas no es demasiado antiguo, y es producto ya de una cierta pretensión conceptual. Lo que se impone primero no es la «equidad» sino «lo bueno y equitativo». Desde muy pronto se conocen las llamadas acciones in aequum et bonum conceptae ${ }^{18}$.

En sus inicios, lo equitativo servía para suplir y completar un derecho escrito escaso, y para humanizar un derecho escrito a veces riguroso, incluso cruel. «La experiencia romana nos enseña que desde los tiempos más antiguos y sobre todo en los siglos anteriores a Cristo (edad "arcaica” y "preclásica" del desarrollo jurídico romano), las rígidas normas del derecho (y en particular las del ius civile) fueron frecuentemente incluso contradichas y acantonadas en

${ }^{17}$ P. G. CARON, «Aequitas» romana, «Misericordia» patristica ed «Epicheia» aristotelica nella dottrina dell'«Aequitas» canonica (dalle origini al rinascimento), Dott. A. Giuffrè, Milano 1971.

18 Acciones que concedían al juez la facultad de decidir según le pareciera justo y equitativo, sin imponer taxativamente un modelo condenatorio específico. Se consideran acciones in aequum et bonum conceptae: a) actio iniuriam aestimatoria; b) actio supulchri violati; c) actio de effusis et deiectis; d) actio rei uxoriae; e) iudicium de moribus; f) iudex qui litem suam facit; g) actio edilicia de feris; h) actio funeraria; i) actio negotiorum gestorum (cfr. G. CIULEI, L'équité chez Cicéron, Adolf M. Hakkert, Amsterdam 1972, 9).

19 A. GUARINO, «Equità. Diritto romano», en Novissimo Digesto Italiano, VI, Unione tipograficoeditrice torinese, Torino 1960, 620 [traducción propia]. 
nombre de la aequitas ${ }^{19}$. Lo cierto es que la intervención de los pretores, cada vez más influyente, «llega a construir un ordenamiento paralelo, un ius praetorium $\mathrm{u}$ bonorarium, derecho pretorio que corrige y completa las deficiencias del estricto ius civile» ${ }^{20}$, y todo eso se lleva a cabo por remisión a lo aequum/iniquum, es decir, como fruto de la apreciación de los desequilibrios que la aplicación de la ley de las doce tablas producía sobre una realidad social que había sufrido numerosos cambios. «El praetor urbanus (imitado por los otros magistrados con competencia judicial) asumió abiertamente la iniciativa de llevar a la práctica, en la resolución de los litigios sometidos a su jurisdicción, las instancias de renovación que se manifestaban en la conciencia

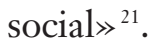

En el derecho romano postclásico se establece el concepto de equidad como idea de perfecta justicia. Y por tanto con un uso amplísimo y difícilmente abarcable. Puede usarse como sinónimo de derecho, pero puede ser también un recurso para complementar y purificar el derecho escrito, para inspirarlo, para interpretarlo, para reformarlo ${ }^{22}$. La influencia helénica da consistencia al vocablo y le atribuye una cierta densidad dogmática y académica, sobre todo desde la perspectiva del estoicismo.

En el camino de la aequitas romana hasta el ius commune medieval hay dos hitos imprescindibles, que son Cicerón y Constantino. No son personalidades aisladas del contexto histórico y doctrinal, pero sí representativas de cómo la equidad va adquiriendo tonos que la aproximan a lo que será mucho tiempo después la aequitas canónica. Cicerón, influido por la ética estoica, será un modelo de comprensión de la ratio iuris, de la verdad que se encuentra más allá del derecho escrito ${ }^{23}$. Rompió una lanza (a veces, es cierto, para proteger intereses personales) en sincera defensa de lo que nosotros podríamos llamar hoy iusnaturalismo ${ }^{24}$. Una ley injusta no merece el nombre de ley más que el decreto ho-

${ }^{20}$ M. J. Bravo Bosch, El «ius honorum» en la antigua Roma, Anuario da Facultade de Dereito da Universidade da Coruña 14 (2010) 240.

21 A. GUARINO, «Equità. Diritto romano», cit., 622. Para una visión general del valor de la aequitas pretoria, cfr. R. MARTINI, «Aequitas» nell'editto del Pretore, Apollinaris 63 (1990) 241-254.

22 Para todo lo referente al concepto de aequitas romana y su historia es muy útil J. UsCATESCU BARRÓN, Acerca de un concepto romano: aequitas. Un estudio bistórico-conceptual, Cuadernos de Filología Clásica. Estudios latinos. Universidad Complutense 5 (1993) 73-104.

23 Sobre la sensibilidad de Cicerón pro bono et aequo y su poco aprecio por la mera letra de la ley, cfr. G. Ciulei, L'équité chez Cicéron, Adolf M. Hakkert, Amsterdam 1972, 32-61.

${ }^{24}$ Las raíces estoicas del derecho natural ciceroniano están muy bien explicadas en O. BuCCI, Per una storia dell'equità, Apollinaris 63 (1990) 273-275. 
micida de un dictador ${ }^{25} \mathrm{o}$ el acuerdo de unos ladrones para delinquir o la receta de unos médicos ignorantes ${ }^{26}$. Quería poner en su sitio el valor de la ley escrita, el ius civile, que contenía algunos anacronismos, numerosos formalismos y bastante aspereza. Se puede decir que Cicerón es el primer autor que lleva a cabo «el repensamiento doctrinal (o como se suele decir, la sistematización "dogmática") de la compleja experiencia» ${ }^{27}$ romana sobre la equidad.

Aunque ya en el antiguo derecho se afirmaban reglas formales de equidad, como la sentencia del jurisconsulto Paulo contenida en el Digesto («in omnibus quidem, maxime tamen in iure aequitas spectanda est» ${ }^{28}$ ), es sobre todo a partir de Constantino cuando el derecho romano del bajo imperio aduce ya la humanidad y la misericordia con un espíritu que quiere distinguirse del paganismo. En el Codex Iustinianus se encuentra la Lex Placuit, de los emperadores Constantino y Licinio: «Placuit in omnibus rebus praecipuam esse iustitiae aequitatisque quam stricti iuris rationem» (en todas las cosas debe prevalecer el criterio de justicia y de equidad por encima del criterio del derecho estricto) ${ }^{29}$. También debe recordarse una ley constantiniana que, como veremos, tendrá relieve en el futuro: «Inter aequitatem iusque interpositam interpretationem nobis solis et oportet et licet inspicere» (Sólo a mí [el emperador] me corresponde interpretar y es lícito que interprete lo que es equidad y lo que es dere-

25 «Iam vero illud stultissimum, existimare omnia iusta esse quae scita sint in populorum institutis aut legibus. Etiamne si quae leges sint tyrannorum? Si triginta illi Athenis leges inponere voluissent, et si omnes Athenienses delectarentur tyrannicis legibus, num idcirco eae leges iustae haberentur? Nihilo credo magis illa quam interrex noster tulit, ut dictator quem vellet civium nominatim aut indicta causa inpune posset occidere. Est enim unum ius quo devincta est hominum societas et quod lex constituit una, quae lex est recta ratio imperandi atque prohibendi. Quam qui ignorat, is est iniustus, sive est illa scripta uspiam sive nusquam. Quodsi iustitia est obtemperatio scriptis legibus institutisque populorum, et si, ut eidem dicunt, utilitate omnia metienda sunt, negleget leges easque perrumpet, si poterit, is qui sibi eam rem fructuosam putabit fore. Ita fit ut nulla sit omnino iustitia, si neque natura est et ea quae propter utilitatem constituitur utilitate alia convellitur» (CICERÓN, De legibus 1.42).

26 «Quid quod multa perniciose, multa pestifere sciscuntur in populis, quae non magis legis nomen adtingunt, quam si latrones aliqua consensu suo sanxerint? Nam neque medicorum praecepta dici vere possunt, si quae inscii inperitique pro salutaribus mortifera conscripserint, neque in populo lex, cuicuimodi fuerit illa, etiam si perniciosum aliquid populus acceperit. Ergo est lex iustorum iniustorumque distinctio, ad illam antiquissimam et rerum omnium principem expressa naturam, ad quam leges hominum diriguntur, quae supplicio inprobos adficiunt, defendunt ac tuentur bonos» (CICERÓN, De legibus 2.13).

27 A. Guarino, «Equità. Diritto romano», cit., 623. Una breve y condensada historia de esa compleja experiencia puede encontrarse en la propia obra de Guarino (622-624), y también en O. BuCCI, Per una storia dell'equità..., cit., 278-281.

${ }^{28}$ Digesta Iustiniani 50.17.90.

${ }^{29}$ Codex Iustinianus 3.1.8. 
cho $)^{30}$. Pero así como nadie duda de la influencia conceptual de Cicerón en la formulación de la equidad, el influjo de Constantino ha sido más discutido ${ }^{31}$.

\section{LAS DOS ALMAS DE LA EQUIDAD CANÓNICA}

El derecho canónico recibió la aequitas romana conforme a la formulación del derecho justinianeo. ¿Hasta qué punto se puede decir que fue una recepción natural? Ha habido cierta polémica académica sobre este particular. Hay autores que afirman la continuidad estricta entre la aequitas romana y la aequitas canónica, aunque poco a poco esta última adquiriera sus connotaciones propias ${ }^{32}$. Otros autores no consienten que se afirme continuidad alguna entre la aequitas romana y la aequitas canónica. Se hizo relativamente célebre el juicio de Gabriel Le Bras según el cual «Aequitas no significa en absoluto lo mismo según el pretor que según el Hostiense ${ }^{33}$. Sin duda ha sido Pio Fede$1 \mathrm{e}^{34}$ quien con más vigor polémico ha sostenido esta tesis, fundándose en sus propias investigaciones (y en sus propias ideas), y apoyándose también en los trabajos de otros canonistas, sobre todo Charles Lefebvre ${ }^{35}$.

${ }^{30}$ Codex Iustinianus 1.14.1.

31 Cfr. J. GaudeMET, Tradition romaine et reflexion chretienne: Le concept d'«aequitas» au IVe siecle, Apollinaris 63 (1990) 191-204. Gaudemet, que no niega la influencia del cristianismo en el concepto de equidad del bajo imperio, afirma que el uso del vocablo es estrictamente paralelo al de los emperadores paganos (cfr. ibid., 195, passim). «L'argument d'équité n'occupe donc qu'une place limitée dans l'outillage mental de la chancellerie impériale» (ibid., 196).

32 La mayor parte de los tratados lo dan por supuesto (cfr. por todos A. VAN Hove, De legibus ecclesiasticis, H. Dessain, Mechliniae-Romae 1930, 277-281). Algunos lo han afirmado explícitamente, cfr. O. RobledA, L'equità in diritto romano, Apollinaris 51 (1978) 404-414.

33 Pio Fedele escribió un artículo para el libro homenaje a Gabriel Le Bras con el título Nibil aliud est aequitas quam Deus. Le Bras le agradeció el trabajo con una carta personal laudatoria. Las palabras citadas forman parte de ese texto, que Fedele hizo público. Más extensamente, el texto decía: «Comme vous, je n'ai cessé de dire que le droit canon ne se justifie que par la salut des âmes. Que l'on soit agnostique ou dévot, la logique impose cette conclusion. En montrant le lien intime, indisoluble entre aequitas canonica et periculum animarum, vous marquez bien la distance entre les deux droits savants, malgré l'identité apparente du vocabulaire. Aequitas n'a point le même sens chez le préteur et chez Hostiensis» (G. LE Bras, en P. FEDELE, Aequitas canonica, Apollinaris 51 [1978] 415).

${ }^{34}$ Las tomas de posición de Pio Fedele sobre este tema han sido muchas, baste la mención de P. FEDELE, Nibil aliud est aequitas quam Deus, en AA.Vv., Études d'histoire du Droit Canonique dédiées à Gabriel Le Bras, I, Sirey, París 1965, 73-87; IDEM, Aequitas canonica..., cit., 415-439, especialmente 434-438.

35 Más adelante citaremos bastantes trabajos de Lefebvre sobre la aequitas canonica. Baste ahora recordar la referencia de su obra más conocida: Ch. LEFEBVRE, Les pouvoirs du juge en droit canonique. Contribution historique et doctrinale à l'étude du canon 20 sur la méthode et les sources en droit positif..., cit., 163-212. 
La opinión de Fedele es perfectamente comprensible tomada a la larga. Efectivamente, el Hostiense en el siglo XIII no usaba la palabra aequitas como la usaba un pretor en el siglo III a.C. Es indudable, como veremos, que en la equidad canónica se hacen presentes otras instancias jurídicas además de las fuentes romanas. Pero esto no quita nada a la realidad de que el derecho canónico acogiera las fuentes romanas como suyas; que las empleara y las citara con completa naturalidad, aun con la conciencia de su soberanía para expresar según su carácter propio el concepto de equidad. Ningún canonista se planteó que hubiera dos justicias o dos equidades, una para el imperio y otra para la Iglesia. Simplemente pensarlo sería monstruoso. Si aequitas nibil aliud est quam Deus $^{36}$ no podía haber un Dios para el Imperio y otro para la Iglesia. Evidentemente era la misma equidad. Una misma equidad que se aplica en ordenamientos distintos, en materias jurídicas distintas, en tiempos distintos y según parámetros de sensibilidad distintos. Es una cuestión de temperamento, no de esencia. Dicho de otra manera, existe un profundo potencial de discernimiento y de especificación en el modo de calibrar el comportamiento equitativo.

¿Hacia dónde orienta la sensibilidad canónica el juicio equitativo? Responder no es tan sencillo. Se puede decir, mirando las cosas en la historia, que la aequitas tiene dos almas. Incluso tres, si queremos matizar mucho. Lo que es seguro es que hay dos direcciones que se presentan alternativamente, una que busca la justicia perfecta y otra que busca la moderación benigna. La primera responde más bien al paradigma romano, la segunda parece más bien una conquista de los tiempos cristianos. Ambas son equidad canónica. Las dos pueden mostrar una relación crítica con la ley positiva, aunque no es necesario que suceda.

La orientación que busca la perfecta justicia puede ser a veces todo lo contrario de lo que entendemos por equidad misericordiosa o benigna. Puede ser una respuesta más dura que la solución ordinaria de la ley, por exigencias de salvación de las almas, de escándalo, de especial gravedad de las conductas. Por tanto la justicia puede exigir una respuesta «equitativa» más allá incluso de las exigencias legales, evitando explícitamente cualquier laxitud. Una solución de las que se llaman de tolerancia cero. Evidentemente también puede motivar una respuesta atenuada, si entiende que la justicia lo requiere.

La segunda versión en cambio busca la moderación o la benignidad cuando no existe necesidad de rigor. Busca atemperar los máximos de las leyes rigu-

${ }^{36}$ Cita anónima repetida hasta la saciedad en tiempos medievales y contemporáneos. 
rosas cuando su materia consiente hacerlo. A estas dos modalidades de aequitas se podría añadir la versión equitativa de la epiqueya aristotélica, es decir, el uso que el operador del derecho hace de la justicia para el caso singular, cuando la ley no alcanza a dar razón suficiente de un caso. Cuando deficit propter universalitatem. La formulación genérica del tipo normativo no admitiría verdaderamente contemplar con suficiencia el caso singular en cuestión. Así como las dos primeras versiones buscaban la excelencia de la justicia y la benignidad de la moderación, lo que busca este tercer modo es el realismo y la verdad del singular.

Se ha hecho especialmente popular para connotar la aequitas canonica la fórmula del Cardenal Hostiense: iustitia dulcore misericordiae temperata, la justicia atemperada por el dulce sabor de la misericordia ${ }^{37}$. La expresión de Enrique de Segusio, el cardenal Hostiense, remite a san Cipriano, aunque no tenemos certeza de que fuera de san Cipriano ${ }^{38}$. La expresión, como digo, hizo fortuna y sirvió para connotar en la doctrina y en la praxis a la aequitas canoni$c a$. Tiene el valor de presentar la justicia como sustancia y la misericordia como temperamento, según el modelo que hemos presentado antes. El dulcor misericordiae quiere indicar que la equidad canónica absorbe aquellas instancias de misericordia exigidas por el derecho de la Iglesia. La equidad canónica no es sólo perfección de la justicia sino una justicia misericordiosa y salvadora. Dicho de otra manera, la perfección de la justicia canónica exige la misericordia y la salvación. No es la misericordia como aditivo yuxtapuesto, sino la misericordia como un criterio específico de perfección de la justicia.

\section{TRES SUCESOS REPRESENTATIVOS PARA LA DOCTRINA}

\section{SOBRE LA AEQUITAS CANONICA}

Los esquemas conceptuales que acabamos de presentar sobre el modo de entender la equidad han sido advertidos bastantes veces. Son modelos extraídos del uso histórico de la aequitas. Se han establecido empleando como base las referencias y los requerimientos que los canonistas y la potestad canónica han hecho de la equidad aquí y allá, en un tiempo y en otro. Pero una vez for-

37 «Aequitas vero media est inter rigorem et dispensationem, sive misericordiam [...] hoc autem a Cypriano sic describitur: Aequitas est iustitia dulcore misericordiae temperata, vel dic quod aequitas est motus rationabilis regens sententiam et rigorem» (HENRICI A SEGUSIO CARDINALIS Hostiensis, Aurea Summa, Lib. V, De dispensationibus 1, Coloniae 1612, 1666).

38 Desde luego, cosas muy parecidas habían dicho ya autores romanos como Aelius Marcianus: $\ll[\ldots]$ in levioribus causis proniores ad lenitatem iudices esse debent, in gravioribus poenis severitatem legum cum aliquo temperamento benignitatis subsequi» (Digesto 48.19.11). 
mulado el esquema es muy importante no olvidar de dónde proviene. Me parece muy conveniente que las afirmaciones genéricas de tipo especulativo, utilísimas por lo demás, puedan contemplarse en la vida, observar cómo han funcionado en la práctica, en la fenomenología canónica.

De modo que lo que pretendemos ahora es una cierta deconstrucción después de la construcción. Para que las palabras no queden vacías y para que los modelos no acaben siendo quimeras es muy conveniente volver a verlos vivir. En realidad los conceptos son abstraídos por inducción de los hechos. Pero si no volvemos a ilustrarlos con las vicisitudes históricas que estuvieron en su origen es posible que lo que entendemos hoy por rigor o por misericordia no sea exactamente aquello en lo que estaba pensando el operador del derecho del siglo XIII.

Antes he hecho un alegato sobre la actualidad de la aequitas canónica, es decir sobre la posibilidad de emplear en el siglo XXI las consecuencias extraídas por los juristas y canonistas del siglo XII o del siglo XIV. Resulta que ahora pongo en guardia sobre el sentido de las palabras de entonces y de ahora, sobre el uso de las categorías jurídicas. Puede parecer que estoy tirando piedras contra mi propio tejado. De todos modos sigo manteniendo lo que dije. Mientras quepa distinguir entre las palabras empleadas y los fines pretendidos, el derecho canónico mantiene a través de la historia una intención coherente sobre la equidad, siempre que sepamos traducir bien las palabras.

Vayamos pues a los sucesos representativos. Dos de esos sucesos constituyen la base de dos normas canónicas que son los pasajes príncipes que la doctrina cita cuando se habla de equidad. El primero es una epístola de san Agustín, recogida en el Decreto de Graciano, que trata sobre la corrección de los donatistas. El segundo texto es del Liber Extra, un pasaje de una decretal de Honorio III al delegado pontificio en Constantinopla sobre algunos abusos cometidos en la capital imperial por griegos y latinos después de la cuarta cruzada. Estos dos primeros sucesos son resoluciones tomadas con ocasión de disputas de vida eclesiástica. El tercero en cambio es una disputa académica que se convirtió en un acontecimiento doctrinal de gran trascendencia para su tiempo y para el nuestro: el debate entre Martín de Gosia y Búlgaro, dos de los grandes legistas discípulos directos de Irnerio.

No importa tanto el alcance objetivo que cada uno de estos sucesos tuvieron. Lo verdaderamente representativo es que cada uno de ellos, al margen de su importancia objetiva, ha servido a la doctrina canónica para establecer las reglas del comportamiento equitativo. Son clavos de los que cuelga el pensamiento canónico sobre las relaciones entre la misericordia y la justicia. 


\section{La Epístola de San Agustín a Bonifacio}

En la primera parte del Decreto de Graciano, concretamente en el canon 25 de la Distinctio 50, se transcribe un texto de san Agustín. Es una carta que escribe al tribuno Bonifacio sobre la corrección de los donatistas. Bonifacio, a quien Agustín conocía mucho, le había pedido orientación. Graciano titula el canon con este dictum: «Por qué está establecido en la Iglesia que nadie vuelva al clero después de hacer penitencia». El canon dice así: «El hecho de que nadie reciba el estado clerical, o vuelva a él, o permanezca en él después de hacer penitencia por algún delito, no se ha establecido en la Iglesia para hacer desesperar del perdón sino para fijar una disciplina estable. De lo contrario se someterían a discusión las llaves entregadas a la Iglesia, de las que se dijo que lo que abráis en la tierra quedará abierto en el cielo. Para que en todos los delitos no se sujetase uno a la penitencia con soberbia, por deseo de honores eclesiásticos, se dispuso con la máxima severidad que después de la penitencia por un crimen que merecía esa pena, nadie fuese clérigo. De modo que la pérdida de toda esperanza de honores temporales fuese la mejor y más auténtica medicina para obtener la humildad. También es verdad que el santo David hizo penitencia de sus crímenes mortales y sin embargo se mantuvo en su puesto de honor. Y san Pedro, cuando derramó aquellas amarguísimas lágrimas, se arrepintió desde luego de haber negado al Señor, y sin embargo permaneció como Apóstol. Pero no por eso hay que considerar inútil la vigilancia de los que vinieron después, que, siempre que no afectase a la salvación de las almas, decidieron agregar un poco de humildad para consolidar la salud del conjunto, conscientes, creo yo, de que algunos fingían penitencias influidos por el deseo de honores. Sufrir muchas enfermedades obliga a encontrar muchos remedios. De todas formas es verdad que en aquellas causas en las que por las desavenencias de un grave conflicto no es que haya peligro para éste o aquél, sino que está en juego un verdadero desastre para todo el pueblo, se debe disminuir un tanto la severidad para que la caridad sincera ayude a sanar males mayores ${ }^{39}$.

39 «[Quare constitutum est in ecclesia ne post paenitentiam quis ad clericatum redeat] Ut constitueretur in ecclesia, ne quisquam post alicuius criminis paenitentiam clericatum accipiat, vel ad clericatum redeat, vel in clericatu maneat; non desperatione indulgentiae, sed rigore factum est disciplinae. Alioquin contra claves datas ecclesiae disputabitur, de quibus dictum est quae solveritis in terra, soluta erunt et in caelo. Sed ne forte etiam de ceteris criminibus, spe honoris ecclesiastici animus intumescens superbe ageret paenitentiam; severissime placuit, ut post actam de crimine damnabili paenitentiam, nemo sit clericus: ut desperatione temporalis altitudinis, medicina maior, et verior esset humilitatis. Nam et sanctus David de criminibus mortiferis paeni- 
Estas últimas palabras se convirtieron en una sentencia común, una especie de proverbio de la doctrina. Cuando se teme por la strages populorum, por la ruina del pueblo, «detrahendum est aliquid severitati, ut maioribus malis sanandis charitas sincera subveniat». ¿Qué quería decir Agustín a Bonifacio? Quería decirle que había que tener mucho cuidado con reducir sin más al estado laical a los obispos donatistas. San Agustín y los obispos católicos de África habían conseguido convencer a los obispos donatistas de su error. Todos ellos estaban dispuestos a rectificar su postura. Pero el pueblo no estaba dispuesto a prescindir de los obispos que habían elegido. Los obispos mismos tampoco querían irse aunque reconocieran que estaban equivocados. En esta situación, en dos concilios sucesivos tenidos en Cartago (407 y 418) los obispos católicos se declararon dispuestos a participar junto con los donatistas en la dirección de sus iglesias. Se produjo así la rarísima circunstancia de tener dos pastores para una misma iglesia. San Agustín preveía un desastre espiritual para el África cristiana si se producía el recambio total de los obispos donatistas.

Me gustaría añadir que la posición de Graciano ante este texto es, como en toda su obra, de concordancia. Este texto tan ponderado de san Agustín, que recoge a su vez un aspecto riguroso del derecho antiguo (ningún clérigo penitente vuelva a ejercitar su oficio) no es la única norma de la distinctio 50 sobre el particular. Hay 49 cánones en esa distinctio, muchos de ellos favorables a que los clérigos arrepentidos puedan volver a ejercitar su oficio después de hacer penitencia. Por tanto, el canon 25 es un comentario al rigor iuris más que al ius. En otras palabras, el rigor es derecho escrito, el ius también es derecho escrito; hay que saber cuándo emplear uno y otro.

Fijémonos en lo que dice al pie del canon 25 la glosa ordinaria al Decreto $^{40}$ : «Una cosa es el rigor, otra el ius, otra la dispensatio. El rigor es un cierto

tentiam egit, et tamen in honore suo perstitit. Et Beatum Petrum, quando amarissimas lacrymas fudit, utique Dominum negasse paenituit, et tamen Apostolus mansit. Sed non ideo supervacua putanda est posteriorum diligentia, qui ubi saluti nihil detrahebatur, humilitati aliquid addiderunt, quo salus totius muniretur, experti, credo, aliquorum fictas paenitentias per affectatas honorum potentias. Cogunt enim multas invenire medicinas, multorum experimenta morborum. Verum in huiusmodi causis, ubi per graves dissensionum scissuras non huius, aut illius hominis est periculum, sed populorum strages iacent, detrahendum est aliquid severitati, ut maioribus malis sanandis charitas sincera subveniat» (Decretum D. 50, c. 10; SAN AGUSTín, Epistola al tribuno Bonifacio sobre la corrección de los donatistas [PL 33, Ep. 185, n. 45, col. 812-813]).

${ }^{40}$ Sobre el trinomio rigor, ius, dispensatio, cfr. E. BAURA, Misericordia e diritto nella Chiesa, en E. GÜTHOFF - S. HaERING (Herausg.), Ius quia iustum. Festschrift für Helmuth Pree zum 65. Geburtstag, Duncker \& Humblot, Berlín 2015, 23-37. 
exceso de derecho, o sea cierta dureza que se presenta para amedrentar, como el canon que dice que ha de imponerse penitencia al que contrae segundas nupcias [...], y que no hay que administrar la comunión ni siquiera al fin de su vida a los que acusaron sin pruebas suficientes a los clérigos, esto es, a los Obispos [...]; no hay que actuar con este rigor más que donde se tema que cunda el ejemplo del mal [...] porque el rigor es una especie de sutileza del derecho (subtilitas iuris). La dispensa es lo mismo que la relajación del derecho, y no se debe emplear más que en caso de necesidad o de utilidad [...]. El ius es el escalón medio entre el rigor y la dispensa $\gg^{41}$.

\section{LA DECRETAL EX PARTE TUA DE HONORIO III}

La siguiente cita de importancia corresponde a la Decretal Ex parte tua de Honorio III, que se encuentra en el primer libro de las decretales de Gregorio IX (X 1.36.11). El romano pontífice responde en torno a 1220 al Cardenal Juan, delegado pontificio en Constantinopla. Después de la toma de Constantinopla por los ejércitos de la cuarta cruzada parecía inminente la unión de los orientales. Así se lo decía gozosamente el Emperador Balduino a Inocencio III el año 1204, y así lo pensaba también el Papa por la misma fecha. Los años, sin embargo, se iban encargando de demostrar que el asunto no era tan sencillo. Ni la toma de Constantinopla ni el nombramiento de un Patriarca latino en la ciudad habían producido muchos progresos en orden a la unión; los griegos continuaban fieles a su Patriarca y a sus instituciones y los coloquios celebrados con los latinos para conseguir el reconocimiento del Primado romano y la obediencia al Papa habían sido decepcionantes. Eso llevaba también muchos problemas de disciplina.

El caso es presentado así por la glosa ordinaria de Bernardo de Parma: «Algunos griegos recibían las órdenes sagradas de modo oculto, no administradas por sus obispos. Algunos también celebraban en iglesias que tenían

${ }^{41}$ «Et nota quod aliud est rigor, aliud est ius, aliud est dispensatio. Rigor est quidam excessus iuris, et quaedam austeritas facta ad terrorem, secundum quod dicit canon, quod poenitentia imponitur contrahenti secundas nuptias [...] et quod communio non est danda etiam in fine vitae his, qui defecerunt in accusatione clericorum, hoc est, Episcoporum [...] et rigor non est servandus, nisi ubi timetur exemplum mali [...] quandoque tamen rigor est idem, quod subtilitas iuris [...]. Dispensatio est idem, quod iuris relaxatio: et ea non est utendum nisi sit necessitas, vel utilitas [...]. Ius autem media strata incedit inter rigorem, et dispensationem» (D. 50, c. 25 gl. v. detrabendum est). 
prohibidas, y no querían obedecer a los latinos. $\mathrm{Y}$ otros obispos, tanto griegos como latinos, llevaban a cabo consagraciones en diócesis ajenas, y percibían allí los diezmos, con perjuicio y agravio de los titulares. También algunos laicos griegos por propia voluntad abandonaban a sus mujeres y se unían a otras mientras vivían las primeras. Otros ocupaban las abadías y las iglesias con fieles de sus propias iglesias, y llevaban a cabo otros muchos excesos, como se dice en el texto escrito. Sobre todos estos excesos el Cardenal consultó al Papa cómo debía proceder ${ }^{42}$. Honorio III responde: «Puedes mediar para lograr una solución; y a veces reducir la severidad en la medida en que veas que es necesario (bien ponderada la situación social y la multitud de posibles vicisitudes); pero hay que exceptuar ciertamente los casos que no admiten arreglo ni dispensa, como el sacramento del matrimonio, que al existir no sólo entre los latinos y los griegos, sino también entre los fieles y los infieles, nunca será lícito apartarse de la severidad canónica al juzgar en torno a él. Pero en las cosas sobre las que no se encuentra derecho expreso procede (observando la equidad) inclinándote hacia la parte más benigna, según veas que lo piden las personas, las causas, los lugares y los tiempos» ${ }^{43}$.

En este caso se hicieron célebres, como símbolo de la equidad misericordiosa, las palabras semper in bumaniorem partem declinando, secundum quod personas et causas, loca et tempora videris postulare. Claro está que para entenderlas en su justo sentido es necesario pensar en que Honorio III está hablando de las situaciones en las que ius silet, o sea aquellas para las que no se encuentra derecho expreso. Y que excluye con mucho vigor que se puedan encontrar soluciones de componendas (compositionis) para la realidad matrimonial.

$42 \ll$ Casus. Quidam Graeci furtive recipiebant sacros ordines a non suis episcopis. Quidam etiam celebrabant in ecclesiis interdictis, nec volebant obedire Latinis: Et quidam alii Graeci et Latini episcopi consecrationes celebrabant in episcopatibus aliorum, et decimas percipiebant ibidem in eorum preiudicium et gravamen. Item quidam laici Graeci proprias uxores auctoritate sua dimittebant, alias illis viventibus recipientes: Et quidam alii abbatias et ecclesias cum hominibus ecclesiarum detinebant, et in aliis etiam pluribus excedebant ut dicitur in integra: super his excessibus Cardinalis consuluit Papam qualiter esset in istos agendum, et ipse hic respodet prout sequitur» (Gl. Casus, ad X 1.36.11).

43 «Ex parte tua: et infra. Poteris ad componendum interponere partes tuas; et interdum aliquid severitati detrahere, prout (statu imperii, et excedentium multitudine provida deliberatione pensatis) videris expedire; exceptis nimirum casibus, qui compositionis sive dispensationis remedium non admittunt, utpote coniugii sacramentum, quod cum non solum apud Latinos et Graecos, sed etiam apud fideles et infideles existat, a severitate canonica circa illud recedere non licebit. In his vero super quibus ius non invenitur expressum, procedas (aequitate servata) semper in humaniorem partem declinando, secundum quod personas et causas, loca et tempora videris postulare» $(X 1.36 .11)$. 
Sobre esto es muy clara también la glosa a la decretal. Dice Bernardo de Parma: «Es evidente que en el matrimonio no tiene lugar la transacción o el compromiso, como si se pudiera establecer algo que tocase a la institución matrimonial: ya fue instituida por el Señor mismo en el paraíso: porque a los que Dios unió, que el hombre no los separe ${ }^{44}$. La glosa ordinaria comenta también la expresión de la decretal directamente referida a la equidad (aequitate servata). Es una expresión cercanísima a la que se encuentra ahora en el c. 19 . «El juez siempre debe tener la equidad delante de los ojos [...]. Así se sigue de lo que dice el texto; en aquello en lo que no encuentres ius expressum, procede según equidad, etc., porque el ius siempre es preferible a la equidad [...] Puede entenderse que la equidad escrita debe preferirse al rigor iuris, pero aquí se habla de la equidad no escrita, que sólo se observa cuando falta $i u s \gg^{45}$.

\section{La disputa Entre Martín de Gosia y Búlgaro}

Esta glosa de las decretales nos pone en el escenario de la polémica doctrinal de la que hablábamos. No es entre canonistas sino entre juristas civiles, pero naturalmente se trasladó a la larga al derecho canónico.

En la Bolonia de mediados del siglo XII sobresalían los «cuatro doctores», es decir, los cuatro grandes discípulos de Irnerio: Búlgaro († 1166), Martín Gosia († ca. 1167), Jacobo († ca. 1178) y Hugo († ca. 1170), que «fueron los primeros artífices de la grandeza del alma mater, normalizaron la enseñanza en ella, abrieron cada vez más las glosas a contenidos técnico-jurídicos más allá del análisis verbal [...] y de la sistemática del texto [...] y provocaron vivas polémicas ${ }^{46}$. La más conocida de esas dissensiones fue la que tuvieron Búlgaro y Martín. Juan Basiano, Azón y Odofredo convirtieron pocos años más tarde en proverbial el antagonismo entre Búlgaro y Martín ${ }^{47}$.

\footnotetext{
44 «Sacramentum. Sic patet quod in matrimonio non habet transactio seu compositio locum, ut in matrimonium aliquid statuatur: cum sit statutum ab ipso Domino in paradiso: Quia quos Deus coniunxit, homo non separet» (Gl. Sacramentum, ad X 1.36.11).

45 «Aequitate. quam iudex prae oculis semper debet habere [...]. Et ita videtur ex eo quod dicit; in quibus ius non invenitur expressum, procedas aequitate, etc, quia ius semper sit praeferendum aequitati [...] Sed potest intelligere illud de aequitate scripta, quae debet praeferri rigori iuris, hic de aequitate non scripta, quae tunc solum servanda est cum ius deficit» (Gl. Aequitate, ad $X$ 1.36.11).

${ }^{46}$ E. CORTESE, «Legistas», DGDC V, 40.

${ }^{47}$ Cfr. ibid.
} 
La polémica se plantea sobre la interpretación de dos leyes que se contenían en el Codex Iustinianus. Una ya la conocemos, era la ley Placuit: «Placuit in omnibus rebus praecipuam esse iustitiae aequitatisque quam stricti iuris rationem» [queda establecido que el criterio de justicia y de equidad se sobrepone siempre al criterio de derecho estricto (CI 3.1.8)]. La otra era la ley Inter aequitatem: «Inter aequitatem iusque interpositam interpretationem nobis solis et oportet et licet inspicere» [sólo a mí (el emperador Constantino) me corresponde y es legítimo que haga una interpretación entre lo que es equidad y lo que es derecho (CI 1.14.1)]. Estas dos leyes, de redacción muy sencilla, parecen sin embargo entrar en colisión. La primera dice que siempre hay que preferir la equidad frente al ius strictum; pero la segunda dice que sólo al emperador le es lícito interpretar qué es equidad.

Antes de nada veamos cómo concebían la equidad los glosadores medievales, legistas y canonistas. La equidad «puede encontrarse en dos estados: uno bruto, informe, indefinido (aequitas rudis, inconstituta, nondum constituta, primaeva), y que corresponde al sentimiento primordial y natural de lo que es equitativo, que se encuentra en cada hombre; frente al cual se halla la equidad transformada en preceptos (aequitas constituta), o sea, el Derecho mismo $($ ius $) \gg^{48}$. La equidad es la justicia originaria. Cino de Pistoya tiene una magnífica metáfora sobre el particular. Dice Cino: «La diferencia entre el derecho [ius] y la equidad es como la que hay entre una copa de plata y la plata como materia: la equidad estaba escondida en lugares ocultos, y con las reflexiones y distinciones propias de los entendidos se depura y adquiere la forma del derecho [species iuris], como el mineral de plata se extrae del yacimiento, se disuelve y se refina antes de tomar forma y de convertirse en una copa, o en un vaso de otro tipo, o en un objeto cualquiera. Entre la justicia y la equidad en cambio la distinción se lleva a cabo de otra forma, porque la justicia mira al alma y la equidad a las cosas mismas. Por lo tanto la equidad es la armonía objetiva [rerum convenientia]; en consecuencia, si queremos ser fieles a las palabras, hay que llamar justo al juez y equitativo al juicio» ${ }^{49}$.

48 A. GUZMáN BRITO, La historia dogmática de las normas sobre interpretación recibidas por el Código civil de Chile, en AA.Vv., Interpretación, integración y razonamiento jurídicos, Universidad Jurídica de Chile, Santiago de Chile 1992, 51-52.

49 «Tanta est enim differentia inter ius et aequitatem quanta est inter cyphum argenteum et materiam argenteam: aequitas enim latebat in suis occultis finibus, et propter elimationes et disputationem prudentium elimatur et reducitur in speciem iuris [...] sicut et materia argentea trahitur de mineria et purgatur et elimatur antequam specificetur, deinde fit species aut cyphi aut alte- 
Explicaremos brevemente la polémica siguiendo en líneas generales la narración que hacen Ennio Cortese ${ }^{50}$, Eduard Meijers ${ }^{51}$ y Alejandro Guzmán Brito ${ }^{52}$.

Búlgaro († 1166), el primero de los discípulos de Irnerio, solucionó la contrariedad de las leyes diciendo que la ley Placuit, que se manifiesta favorable a la equidad frente a la ratio stricti iuris, quiere distinguir entre «equidad» $\mathrm{y}$ «derecho estricto», no entre «equidad» $\mathrm{y}$ «derecho». La ley no estaría refiriéndose a la equidad ruda sino a la aequitas constituta, hecha ya precepto, pero opuesta a lo que llama la ley Placuit «derecho estricto». Hay normas rigurosas y duras que se oponen a otras normas mitigadas o benignas. Esas normas mitigadas son aequitas scripta y son preferibles a las normas rigurosas, normalmente sancionadoras o penales.

La otra ley, la Inter aequitatem, se refiere simplemente a la aequitas rudis; y viene a decir que sólo el legislador es competente para convertir la equidad primordial en derecho positivo. El juez o el académico no son competentes para transformar la equidad ruda en equidad constituida o en ius. Eso haría correr al derecho demasiados riesgos. En definitiva, haría posible elevar a rango de norma pública intereses contingentes. De aquí surgieron múltiples calificaciones burlonas y mordaces de la equidad ruda que extrae imaginarias motivaciones ex ingenio suo, ex capite suo, de corde suo o ex bursa sua.

Todo ello era una respuesta al otro disputante, el glosador Martín Gosia († ca. 1167), igualmente discípulo de Irnerio. Martín intentó conciliar las dos leyes de otro modo. La única interpretación que obliga a todos (general y necesaria) es la del legislador. Eso es lo que quiere decir la ley Inter aequitatem. Pero para el juez y el doctor vale la ley Placuit; es decir, el juez y el académico pueden servirse de la aequitas rudis. Ellos llevan a cabo interpretaciones que no son generales aunque puedan ser obligatorias, o que no son ni siquiera obliga-

rius vasis vel speciei, vel alio modo differunt iusticia et aequitas; quia iusticia respicit animam et aequitas res ipsas: unde aequitas est rerum convenientia, et ideo secundum proprietatem verborum debet dici iudex iustus et iudicium aequum» (CyNus PisToriensis, In Codicem et aliquos titulos primi Pandectorum Tomi, id est, Digesti veteris, doctissima Commentaria, Lib. 1, tit. 14, 1.1, Inter aequitatem, n. 9, Francofurti ad Moenum 1578, Torino 1964 [rist.], fol. 25 r.).

${ }^{50}$ E. CORTESE, «Legistas»..., cit., 40-41.

51 E. M. MEIJERS, Le conflit entre l'équité et la loi chez les premiers glossateurs, en IDEM, Etudes d'histoire du droit, IV (ed. R. FEENSTRA - H. F. W. FiSCHER), Universitaire pers Leiden, Leyde 1966, 142-156.

52 A. GUZMÁN BRITO, La historia dogmática de las normas sobre interpretación recibidas por el Código civil de Chile..., cit., 51-54; IDEM, Ratio scripta, Klostermann, Frankfurt am Main 1981, 12-22. 
torias sino simples orientaciones doctrinales (como el caso de la interpretación doctoral). La ley Placuit obliga a preferir la equidad sobre el ius, dice Martín.

La opción hermenéutica de Martín no obtuvo muchos adeptos entre los juristas civiles ${ }^{53}$. Su misma exégesis textual de la ley Placuit levantaba algunas sospechas. En efecto, la ley Placuit no habla simplemente de ius, sino de ius strictum; y con bastante probabilidad no se estaba refiriendo a la aequitas rudis sino a la aequitas constituta. En general la aequitas martiniana fue muy vilipendiada entre los legistas. Se le llamó aequitas cerebrina, capitanea, bursalis. Como «para indicar esa suerte de autorización que en definitiva Martín había querido conferir al juez y al doctor, de modificar el Derecho constituido en favor de una solución supuestamente equitativa, pero que en realidad podía ser nada más que especulativa o imaginaria» ${ }^{54}$. Los discípulos directos de Búlgaro, como es el caso de Rogerio, tienen diatribas muy duras sobre equidad martiniana: «En este caso y en otros parecidos en los que se plantea la cuestión entre el ius y la aequitas rudis, la interpretación se la reservan los príncipes: ellos son los que tienen potestad sobre las leyes, y pueden corregirlas y establecerlas. Los estúpidos lo contradicen, pensando que a ellos todo les está permitido, afirmando también desvergonzada y temerariamente que ellos conocen una equidad que no conocen, y prefiriendo su propio ingenio a la autoridad de los príncipes establecida con claridad en la ley» ${ }^{55}$.

Curiosamente en el siglo XX hemos tenido también un episodio semejante en el modo como algunos juristas de renombre han juzgado la aequitas romana postclásica. Decía por ejemplo Guarino: «[...] en la valoración de las instituciones singulares y los supuestos de hecho concretos, la aequitas postclásica en realidad no tiene límites y sirve para autorizar cualquier aberración. Se manifiesta verdaderamente como una perniciosa "justicia del caso concreto", que los juristas y los emperadores aducen para sostener cualquier antojo o solución

${ }^{53}$ Se pueden tal vez adscribir a los favorables, al menos en algunos aspectos, a la aequitas martiniana la Summa Trecensis, Vacarus, Karolus y Placentinus. Cfr. E. M. MeIJERS, Le conflit entre l'équité et la loi chez les premiers glossateurs..., cit., 145-148.

54 A. GuZMán BRITO, La historia dogmática de las normas sobre interpretación recibidas por el Código civil de Chile..., cit., 53.

55 «In hoc casu et similibus, quibus inter ius et equitatem rudem questio vertitur, sibi dumtaxat interpretationem divi reservant principes: hic enim, sicuti soli legibus presunt, sic eas corrigere soli possunt, uti et facere. Quod stulti (sibi licere quodlibet putantes, equitatem quoque, quam non noscunt, se scire inverecunde temereque asserentes, legibus apertis principum auctoritati suum preferentes sensum) contradicunt» (Rogerii Enodationes quaestionum super Codice, 3, en H. KaNTOROWICZ - W. W. BuCKLAND, Studies in the glossators of the Roman law. Newly discovered writings of the 12th century, Scientia Verlag, Aalen 1969 [1938] 284). 
cómoda para los problemas espinosos y delicados. Y de modo inevitable la aequitas termina siendo, en la práctica, la cómoda justificación del laxismo en el derecho: una expresión de benignitas, de bumanitas, de pietas, de caritas, es decir, de valores cristianos altamente admirables desde el punto de vista religioso, pero reprobables en la misma medida desde el punto de vista jurídico» ${ }^{56}$. Una singular coincidencia, sin duda muy discutible pero que explica muy bien los riesgos de la aequitas rudis. Guarino finaliza su trabajo con estas duras palabras: «Aunque han transcurrido quince siglos desde los últimos tiempos de Justiniano, son tal vez estos valores tan antirromanos, dentro de la compleja experiencia romana de la aequitas, los que por desgracia identifican la equidad a los ojos de la gente de la calle y de los mismos operadores del derecho» ${ }^{57}$.

Pero volvamos a la Bolonia del siglo XII. Sería un error identificar a los partidarios de la aequitas constituta con los positivistas y a los de la aequitas rudis con los iusnaturalistas. La dissensio «no debe ser entendida como una disputa entre iusnaturalistas y positivistas, para emplear una terminología actual. Con la misma terminología, todos aquellos juristas eran iusnaturalistas, pues para todos era evidente que el principio supremo del Derecho estaba en la equidad. Más aún, para ellos el Derecho positivo era una escrituración de la equidad, en la medida en que ellos identificaban ius y aequitas constituta ${ }^{58}$. Por otra parte, el mismo Martín Gosia, si hemos de creer a Azón, «inhaerebat literae tanquam iudaeus» ${ }^{59}$, es decir, no se podía considerar un liberal o un jurista irrespetuoso con el texto legislativo.

\section{LA INCIDENCIA DE LA POLÉMICA EN EL DERECHO CANÓNICO}

Entre los canonistas la posición de Martín no fue ni mucho menos tan desacreditada. El cardenal Hostiense pondera la posición de Martín, al que considera «spiritualis homo»; y en cambio combate con rigor a uno de sus ad-

A. GUARINO, «Equità. Diritto romano»..., cit., 624.

Ibid.

58 A. GUZMán BRITO, La historia dogmática de las normas sobre interpretación recibidas por el Código civil de Chile..., cit., 53-54.

59 AzÓN, Lectura Codicis ad 7.51.2. Por otra parte, en la valoración que hacía Irnerio de sus discípulos en su lecho de muerte, evidentemente legendaria, Martín quedaba como el más pegado a la letra: «Bulgarus os aureum, Martinus copia legum, mens legum est Ugo, Jacopo id quid ego». Este juicio legendario de Irnerio fue transcrito por Otón y Acerbo (hijo de Otón) Morena, contemporáneos de los cuatro discípulos de Irnerio, en su Crónica, que cuenta las vicisitudes de la vida pública lombarda entre 1153 y 1167. 
versarios, Juan Basiano, de quien dice que «non sapiebat quae sunt spiritus» ${ }^{60}$. Pero a la larga, aunque el derecho canónico ha sido más sensible a los dictados de la aequitas, ha terminado por prevalecer el valor de la llamada aequitas scripta o aequitas constituta.

¿Qué razones pudieron existir para que el planteamiento de Enrique de Susa, el Cardenal Hostiense, uno de los decretalistas más reconocidos y prestigiosos, no lograra introducir en el ámbito de la doctrina canónica sus ideas sobre la aequitas? ¿Qué razones pudo haber, sobre todo, cuando esas ideas parecían profundamente evangélicas, la posición eclesiástica del Hostiense era reconocidísima, y toda la canonística repetía además su afortunada conceptualización de la equidad canónica como iustitia dulcore misericordiae temperata?

Giuliano Brugnotto pondera el valor de la aportación de Enrique de Susa y advierte a la vez que «no podemos callar un límite que nos parece que constituye la causa de su irrelevancia histórica, una vez que prevaleció la línea más rigurosa desde el siglo $\mathrm{XIV} \gg^{61}$. Esa causa sería la incerteza en que deja Enrique de Susa a la doctrina y a la praxis jurídica. «Se tiene la impresión de que nuestro autor no llega a determinar con claridad el papel que juega la equidad. Da la impresión de que para el juez, pero el mismo argumento vale para el intérprete de la ley, no queda otra vía que descubrir personalmente la dirección de la ley siguiendo una "conciencia jurídica" [...] Enrique de Susa, que no deja de seguir ciertamente el camino más seguro para la salvación del alma, deja abierta la noción de equidad a determinaciones más específicas que han de ser acogidas en la argumentación jurídica. La expresión sintética "aequitas est iustitia dulcore misericordiae temperata" ha dado en el corazón de la noción de equidad pero ha dejado en la incerteza al canonista que debe formular, valorar o aplicar la norma» ${ }^{62}$. Este juicio es cierto. Por mucho que Enrique de Segusio entienda bien e

${ }^{60} \ll$ Et sic approbatur hic sententia Martini qui sic intellexit [...]. Et reprobatur opinio Bulgari et Iohannis et sequacium suorum, sicut et in multis aliis. Martinus enim spiritualis homo fuit, et secundum tempus, quod tunc currebat, semper divinae legi adherebat contra rigorem juris civilis, Iohannes vero non sapiebat quae sunt spiritus, sed tanquam animalis, multiplicationi temporalium, et rigori juris civilis, quasi per omnia intendebat. Unde et ipse et sequaces sui qui hodie multi sunt, spirituales opiniones reprehendunt, et dicunt, haec est aequitas capitanea, aequitas bursalis Martiniana. Sed velint nolint, hanc aequitatem de iure habent sequi ubicumque agitur de periculo animarum» (Henrici De Segusio Cardinalis Hostiensis, In Primum Decretalium librum Commenaria, Venetiis: Apud Iuntas, 1581, ad X 1.43 [De arbitris] 9 [Per tuas], 207r.).

${ }^{61}$ G. Brugnotto, L'«aequitas canonica». Studio e analisi del concetto negli scritti di Enrico da Susa (Cardinal Ostiense), Editrice Pontificia Università Gregoriana, Roma 1999, 239.

${ }^{62}$ Ibid., 240. 
incluso formule con éxito la definición de equidad canónica (de un modo vaguísimo, aunque simple y bello), seguimos encontrándonos con el problema de cómo hacer trabajar jurídicamente al concepto si lo convertimos en «canon hermenéutico», es decir, si hacemos de él un modo de dirigir la praxis. Probablemente al Cardenal Hostiense (como a Martín Gosia) esto no le parecería en absoluto problemático, porque apelaría a su conciencia, que era una conciencia virtuosa y bien formada, la conciencia de un hombre equitativo. Pero un canon hermenéutico debe orientar todas las conciencias, debe dar luz de equidad a cualquier conciencia que juzgue. Los cánones hermenéuticos no se hacen para los justos, sino para ser justos.

Enrique de Segusio creía que incluso la opinión jurídica de Sinibaldo dei Fieschi (Inocencio IV) resultaba «demasiado civil, demasiado sutil» ${ }^{63}$, que quiere decir demasiado preocupada por la certeza del derecho, demasiado exigente, demasiado formal. Pero esta posición del Cardenal Hostiense no prevaleció. Los canonistas, conforme tuvieron sus propias leyes, entendieron generalmente que ese derecho positivado era sustancialmente equitativo y no estaba dominado por las subtilitates iuris. Era algo reconocido no sólo por los canonistas sino por los legistas ${ }^{64}$. La corriente general de la canonística entre el siglo XV y el siglo XX (obviamente una expresión tan general podría ser

${ }^{63} \ll[. .$.$] nimis videtur fuisse civilis, nimis subtilis; quamvis enim praedicta in omnibus civilibus$ quaestionibus locum habere possint, in spiritualibus tamen non est ita subtiliter procedendum, sed potius de bona fide agendum, et animarum periculis occurrendum» (HENRICI DE SEGUSIO Cardinalis Hostiensis, In secundum Decretalium librum Commentaria, Venetiis: Apud Iuntas, 1581, ad X 2.10 [De ordine cognitionum] 2 [Cum dilectus], 37v.).

${ }^{64}$ Sobre este asunto decía Accursio (también en Azón podemos encontrar frases similares): «Quae sententia nobis placet, nam et iure canonico comprobatur, ut extra, de Praesc. c. "Cum vobis", quod imitari debemus [...]. Verum per novissimas Decretales Innocentii omnis praescriptio tollitur: quod scilicet ius canonicum iure naturali firmatur» (ACCURSIUS, Auth. Ut Ecclesia Romana, collatio II, t. 4, gl. «[centrum] annorum», cit. por M. CuYÁs, La buena fe en la prescripción extintiva de deudas. Desde el Concilio IV de Letrán [1215] hasta Bartolo [† 1357], Libreria Editrice dell'Università Gregoriana, Roma 1962, 57). Este último autor afirma: «Me complazco en hacer notar dos principios, recogidos en la última glosa citada, que se habían de revelar singularmente eficaces para la aceptación del requisito canónico en el Derecho civil: "Quod [ius canonicum] imitari debemus" y "quod scilicet ius canonicum iure naturali firmatur"» (M. CuYÁs, La buena fe en la prescripción extintiva de deudas, cit., 59). Más absoluto aún es Baldo de Ubaldis: «Nam istud ius gentium est bonum et aequum, ergo servandum et quia potius debemus servare ius canonicum quam ius civile quia canonicum inhaeret iuri divino et sub lege divina sunt omnes populi et nationes, sed ius imperatoris non viget ubique locorum» (BALDUS DE UBALDIS, ad Codicem Iustinianum 6.32.2, cit. por E. M. MEIJERS, L'Histoire des principes fondamentaux du droit International Privé a partir du Moyen Age spécialement dans l'Europe Occidentale, Académie de Droit International. Recueil des Cours 49 [1934/III] 627). 
matizada) se muestra firmemente partidaria de la aequitas scripta y muy crítica con la aequitas rudis. Es más, a partir del siglo XVI con un sistema legal consistente y la pujanza del racionalismo jurídico, la aequitas fue sustituida en la práctica por la epiqueya. Dicho con otras palabras, la equidad ya no se presenta como un ideal jurídico que la propia ley persigue, y que ofrece a la ley soluciones alternativas o supletivas. Se trataba más bien de encontrar los casos en los que la obligación de la ley podía ser excusada. La epiqueya tiene un punto consistente de desarrollo con Francisco Suárez ${ }^{65}$, aunque su itinerario de recepción en la doctrina canónica pasa por Tomás de Aquino ${ }^{66}$, que a su vez recoge la doctrina de la Ética nicomaquea ${ }^{67}$.

${ }^{65}$ Suárez afronta la epiqueya como causa excusante de la ley en el Libro VI del Tractatus de legibus ac Deo legislatore, sobre todo en los capítulos 6-8 (De cessatione obligationis legis in particulari contra verba legis; De excusatione legis per epikeiam; De usu epikeia sine recursu ad principem). Identifica el concepto de epikeia con el de equidad, pero desarrolla la versión aristotélica tomasiana de epiqueya, como «emendationem legis ea ex parte quae deficit propter universalem» (De legibus 6.6.4, en F. SuÁrEZ, Tractatus de legibus ac Deo legislatore. Liber VI: De interpretatione, cessatione et mutatione legis bumanae [C. BACIERO - J. M. GARCÍA AÑoveros, ed. crit.], Madrid 2012, 130). Sobre la epiqueya en Suárez puede verse también O. RobledA, La «aequitas» en Aristóteles, Cicerón, Santo Tomás y Suárez, Miscelánea Comillas 15 (1951) 270-279.

${ }^{66} \ll[. .$.$] cum de legibus ageretur, quia humani actus, de quibus leges dantur, in singularibus con-$ tingentibus consistunt, quae infinitis modis variari possunt, non fuit possibile aliquam regulam legis institui quae in nullo casu deficeret, sed legislatores attendunt ad id quod in pluribus accidit, secundum hoc legem ferentes; quam tamen in aliquibus casibus servare est contra aequalitatem iustitiae, et contra bonum commune, quod lex intendit» (SANTO TOMÁs DE Aquino, Summa Theologiae II-II, q. 120, a. 1 in c.).

${ }^{67} \ll 1137 \mathrm{~b}[. .$.$] Lo que produce la aporía es el hecho de que la epiqueya es sí lo justo, pero no lo jus-$ to según ley, sino más bien un correctivo de lo justo legal. El motivo es que la ley es siempre una norma universal, pero existen casos singulares que no es siempre posible tratar correctamente de modo universal. Por tanto, en las circunstancias en las que es inevitable hablar en universal, pero no se puede hacer con plena corrección, la ley toma en cuenta lo que se verifica en la mayoría de los casos, sin ignorar por eso el error de lo que es meramente aproximativo. No es por eso menos correcta la ley: el error no está en la ley ni en el legislador sino en la naturaleza de la cosa, porque la materia de las acciones tiene precisamente esta característica intrínseca. Por tanto, cuando la ley habla en universal, y a continuación sucede algo que no entra en la norma universal -porque el legislador ha pasado por alto algo y no ha acertado a preverlo, por haber hablado en general- es entonces legítimo corregir la omisión y considerar establecido lo que el legislador mismo diría si estuviese presente, y que habría incluido en la ley si hubiese podido conocer el caso en cuestión. Por eso el ejercicio de la epiqueya es justo, es más, es mejor que un cierto tipo de justo; no de lo justo en sentido absoluto, sino de lo justo por aproximación, del que está formulado universalmente. Y ésta es la naturaleza de la decisión de epiqueya: una corrección de la ley cuando es defectuosa a causa de su universalidad. Éste es en realidad el motivo por el que no todo puede ser definido por la ley: hay casos en que es imposible establecer una ley sino que se requiere dictar una determinación singular. Para una cosa indeterminada, también la norma es indeterminada, como la regla de plomo usada en la construcción de Lesbos: la regla se adapta a la configuración de la piedra y no permanece rígida, como el decreto singular se adapta a los hechos. 
En los siglos sucesivos diríamos que la doctrina no siente una pasión renovada por la aequitas como recurso jurídico específico, mientras considera consolidado el sistema anterior ${ }^{68}$. La aequitas llega al siglo XX con un interés muy modesto de la doctrina canónica. Javier Urrutia se asombraba de que en el monumental Ius Decretalium de Wernz sólo se dedicara a la aequitas un párrafo de pocas líneas en el que se hace una elemental distinción entre la equidad natural y legal ${ }^{69}$. Es verdad que después de la codificación de 1917 los tratadistas codiciales se vieron obligados a comentar las referencias ocasionales de los cánones a la aequitas canonica, sobre todo la del c. 20, orientado a la suplencia de ley. Así aparecieron algunos tratamientos más estructurados y sistemáticos sobre la equidad. Tal vez los de más calidad son el del ya citado Charles Lefebvre y el de Alphonse Van Hove ${ }^{70}$.

Pero en la segunda mitad del siglo XX se produjo un estallido de interés por la aequitas canónica. Fueron dos razones distintas (completamente distintas, diría yo) las que originaron este interés abrupto e intenso ${ }^{71}$. Una fue la dogmática jurídica italiana, vivísima entre los años 1930-1980, que tenía voluntad de justificar el carácter específico del ordenamiento canónico y encon-

Es claro qué es lo decidido por epiqueya; y que eso es justo y mejor que un cierto tipo de justo. De lo cual se desprende también con toda claridad quién es el hombre que actúa con epiqueya: es el que tiende a elegir y a hacer efectivamente cosas de este tipo, y [1138a] que no se deja ganar por el escrúpulo para aplicar la justicia hasta hacer el mal, sino que se siente obligado a refrenarse, aunque tenga el apoyo de la ley. Esta disposición es la epiqueya, que es una forma especial de justicia y no una disposición de género diverso» (ARISTÓTELES, Ética a Nicómaco, 5.10 [1137b-1138a]).

${ }^{68}$ Hasta qué punto lo consideraba consolidado puede advertirse con este juicio de Reiffenstuel: «Notant tamen Doctores [...] allegatam Regulam ["in omnibus casibus potior debet esse ratio aequitatis, quam stricti iuris"] esse intelligendam de aequitate scripta, sive [...] de aequitate a Jure informata, quae nimirum ex Jure colligi potest: non autem de aequitate cerebrina, seu quae ex proprio capite Judicis desumitur. Haec enim non praefertur rigori scripto: aequitas enim cerebrina ex proprio capite Judicis deprompta, non potest dici aequitas, sed iniquitas, quando deviat ab eo, quod veluti iustum, et aequum, per leges constitutum est; cum lex sit fundata super ratione et aequitate [...]. Atque ideo, quia Judex prae oculis habere debet aequitatem Juris, seu scriptam, et a Jure informatam, ipse non debet esse clementior lege [...]. Quod si tamen deficiat aequitas scripta, et in Jure circa aliquod nihil habeatur expressum, tunc locus erit aequitati non scriptae, et secundum quod Judex aequum et justum esse censuerit» (A. REIFFENSTUEL, Ius Canonicum Universum juxta Titulos quinque Librorum Decretalium, Tomus I, 1.2.16, Joannis Hermanni de Gelderen, Monachii 1700, 161).

${ }^{69}$ Cfr. F. J. Urrutia, Aequitas canonica, Apollinaris 63 (1990) 215. Cfr. también G. M. Colombo, Sapiens aequitas. L'equità nella riflessione canonistica tra i due codici, Pontificia Università Gregoriana, Roma 2003, 75.

${ }^{70}$ Cfr. A. Van Hove, De legibus ecclesiasticis, H. Dessain, Mechliniae-Romae 1930, 274-304.

${ }^{71}$ No es posible ni necesario dar razón completa de la bibliografía sobre la equidad en el siglo XX. Pueden ayudar los elencos bibliográficos que presentan O. BuCCI, Per una storia dell'equità..., cit., 287-317; F. J. Urrutia, Aequitas canonica, cit., 233-239; G. M. Colombo, Sapiens aequitas..., cit., 417-438. 
tró en la aequitas un instrumento apropiado para ello $^{72}$. Autores como Pio Fedele, Orio Giacchi, Vincenzo del Giudice, Pier Giovanni Caron, Anna Ravà y otros trataron específicamente sobre la aequitas. La segunda fue el drástico cambio que introdujo el Concilio Vaticano II en la vida eclesial, y que en la mente de muchos pedía una mitigación de las exigencias legales y una ampliación de las soluciones misericordiosas y benignas ${ }^{73}$. Ayudaron también a este interés renovado los discursos de Pío XII ${ }^{74}$ y de Pablo VI ${ }^{75}$ sobre la aequitas canonica. Sobre todo la posición de Pablo VI presentó en público lo que podríamos llamar una «equidad dulce», que sintonizaba en buena medida con las pretensiones de la segunda posición de la que hablamos.

\section{BALANCE DE LAS VICISITUDES HISTÓRICAS}

¿Se puede hacer un balance satisfactorio de esta historia? ¿Se pueden extraer inferencias válidas para nuestra valoración de la aequitas canonica, de la relación entre la justicia y la misericordia? A mí me parece que sí siempre que distingamos bien.

72 Ha sido Charles Lefebvre, y desde el punto de vista polémico Pio Fedele, los que más han batallado por la condición especial y característica de la aequitas canonica, con buenas razones. $\ll \mathrm{Eb}-$ bene, se si vuole intendere veramente quale significato abbia l'aequitas canonica, in contrapposizione col significato che ha l'aequitas romana, bisogna intendersi bene sul significato che hanno, nella economia dell'ordinamento canonico, le parole charitas, benignitas, misericordia. Queste parole, considerate in relazione al tema del periculum animarum, intimamente connesso con quello dell'aequitas, non significano sempre indulgenza, umanità, perdono. Alcuni temi [favorabilitas de la ley penal, obligación de la nuda promissio, principio de que mala fides nocet, etc.] avrebbero dovuto mettere sull'avviso per intendere in che senso si può parlare, quanto all'aequitas canonica, di charitas, di benignitas, di misericordia, ed invece essi sono stati del tutto negletti. E allora si comprende facilmente come il fraintendimento dell'aequitas canonica sia stato fatale: più che al fatto di considerarla circoscritta nell'ambito della pura tecnica ermeneutica, como semplice canone d'interpretazione, como correttivo benigno del rigor iuris, "querula istanza di misericordia e d'indulgenza nell'applicazione della legge ai casi concreti", come si esprime il Calasso [...], quel fatale fraintendimento è dovuto al fatto che, non prestandosi alcuna attenzione all'intimo ed inscindibile nesso che corre tra aequitas canonica e periculum animarum, non si è colto il vero significato che ha la misericordia quante volte sia in giuoco l'esigenza di evitare questo pericolo» (P. Fedele, Aequitas canonica..., cit., 435-436).

73 Un ejemplo característico de esta posición es F. J. URRUTIA, Aequitas canonica..., cit., 205-239. El autor rehabilita la equidad no escrita, pone la medida en actuar según el Evangelio, y critica fuertemente el positivismo de gran parte de la doctrina canónica desde los decretistas hasta el siglo XX por haber empleado una equidad que no tenía raíces canónicas (cristianas).

${ }^{74}$ Cfr. Pío XII, Allocutio 22-IV-1952 (AAS 44 [1952] 371-377).

75 Cfr. Pablo VI, Allocutio 29-I-1970 (AAS 62 [1970] 111-118); Allocutio 28-I-1971 (AAS 63 [1971] 135-142); Allocutio 8-II-1973 (AAS 65 [1973] 95-103). Son todas ellas dirigidas a los prelados auditores de la Rota. 
Se pueden extraer algunas conclusiones sobre la aequitas como canon hermenéutico. Algunos puntos que ayuden a entender el procedimiento práctico que debe seguir la valoración equitativa, o sea, el recurso a la aequitas canónica como medio de corrección y de suplencia. Por otra parte es posible también establecer algunas ideas para discernir los límites y las materias sujetas al juicio equitativo. En este segundo caso no se pretende fijar cuestiones de procedimiento práctico sino trazar la perspectiva conceptual con que opera la aequitas canonica. Se trataría de bosquejar lo que podríamos llamar un «ideario útil», es decir, algunas ideas receptae in doctrina que disciernan un tema que es de suyo denso e indefinido.

Dentro de los puntos del procedimiento podríamos decir que el balance histórico permite establecer los siguientes pasos para la eficacia de la aequitas como recurso jurídico hermenéutico y supletivo: 1) La aequitas rudis puede hacerse valer para suplir la ausencia de ley. 2) En el caso de oposición entre rigor iuris y aequitas scripta, debe elegirse la aequitas scripta como solución común, si no hay otros peligros que causen daño. 3) No se considera nunca equitativo por parte de un juez ir contra la ley, porque la ley es aequitas scripta. 4) Si la ley deficit propter universale, y el supuesto legal no describe con suficiencia el caso, puede aplicarse una solución distinta y más adecuada. Este último punto responde, como se puede apreciar, a la perspectiva propia de la epiqueya.

Veamos las ideas que se pueden considerar recibidas en la tradición y que pueden servir como líneas de discernimiento en nuestra materia: 1) El derecho divino marca una línea insalvable para la intervención benigna; nunca puede ser equitativa una intervención que lesione el derecho divino. 2) La virtud es aequa y el pecado es iniquum; uno de los puntos fuertes de la equidad canónica es evitar el periculum animae. 3) La aequitas canonica impone una subordinación de las formalidades del derecho positivo a las condiciones personales de los actos jurídicos. 4) El derecho canónico es un ius aequum, lo cual no puede darse por supuesto en el caso del derecho civil.

Muchas de estas ideas irán apareciendo a lo largo de la segunda parte de este trabajo, al hilo de las cuestiones que se plantean hoy.

Es probable que las consecuencias que acabamos de extraer como balance histórico no encuentren la aprobación de todos, por varias razones. Algunos tal vez piensen que estas conclusiones son producto de un error histórico. No porque se equivoque el que las recoge ahora, sino porque se equivocaron los canonistas medievales cuando las formularon siguiendo una línea civil y no eclesial. En su opinión, esas conclusiones no pueden convertirse en reglas de 
la aequitas canonica porque no responden al espíritu del derecho canónico. Otros tal vez digan que la equidad canónica puede cambiar, debe cambiar, y ha cambiado de hecho. Se hacen fuertes en la pregunta de Pablo VI: «¿No será tal vez necesario un repensamiento de la aequitas canonica a la luz del Concilio mismo, para conferirle un valor más cristiano y un significado más fuertemente pastoral?» ${ }^{76}$. Prefieren pensar que el tiempo ha conducido a configurar una equidad líquida y blanda, difusiva de suyo como el bien, sin barreras, que se puede aplicar siempre, que puede sanar cualquier herida que cause el derecho, y que puede eliminar cualquier arista del sistema jurídico.

Las aludidas respuestas no me parecen acertadas. Ya he dicho que hay un elemento muy fuerte de continuidad entre el siglo XII y el siglo XXI en las cuestiones que tienen que ver con la justicia y con la equidad. Muchas veces estas cuestiones de continuidad o ruptura son puntos de partida, no de llegada. Si alguien piensa por ejemplo que el Concilio Vaticano II ha supuesto una ruptura con la tradición doctrinal y disciplinar de la Iglesia, necesariamente pensará que también ha existido una ruptura en el modo de entender la aequitas. Pero me parece más sensato pensar que no ha habido una ruptura. Por otra parte una pregunta es una pregunta. Pablo VI hizo muchas otras preguntas. $\mathrm{Y}$ en los cuarenta años que han seguido a aquella pregunta se han sucedido muchas intervenciones pontificias sobre la equidad ${ }^{77}$ que han intentado responder muy matizadamente a la pregunta de Pablo VI.

${ }^{76}$ Y continúa diciendo Pablo VI: «Los principios de la revisión parecen insinuarlo: la sapiens aequitas, de la que hablan, es fruto de benignidad y caridad» (Allocutio 8-II-1973, AAS 65 [1973] 100).

77 Cfr. sobre todo Juan Pablo II, Allocuzione 17-II-1979 (AAS 71 [1979] 422-427); Allocuzione 26II-1983 (AAS 75 [1983] 554-559); Allocuzione 18-I-1990 (AAS 82 [1990] 872-877); Allocuzione 22-V-1992 (Communicationes 24 [1992] 10-12); Allocuzione 28-I-1994 (AAS 86 [1994] 947952); Allocuzione 17-I-1998 (AAS 90 [1998] 781-785). 


\section{Bibliografía}

BAURA, E., Misericordia, «oikonomia» e diritto nel sistema matrimoniale canonico, en C. J. Errázuriz M. - M. A. Ortiz (a cura di), Misericordia e Diritto nel matrimonio, Edusc, Roma 2014, 23-45.

—, Misericordia e diritto nella Chiesa, en E. GüTHOFF - S. HAERING (Herausg.), Ius quia iustum. Festschrift für Helmuth Pree zum 65. Geburtstag, Duncker \& Humblot, Berlín 2015, 23-37.

Bransington, B., «Require in Prologo». The Decretists and Ivo of Chartres' Prologue, Zeitschrift der Savigny-Stiftung für Rechtsgeschichte, kan. Abt. 118 (2001) 84-124.

Bravo Bosch, M. J., El «ius honorum» en la antigua Roma, Anuario da Facultade de Dereito da Universidade da Coruña 14 (2010) 229-248.

Brett, M., «Ivo de Chartres», en J. OtaduY - A. Viana - J. Sedano (eds.), Diccionario General de Derecho Canónico, IV, Thomson Reuters Aranzadi, Cizur Menor (Navarra), 850-852 (en adelante, DGDC).

BRugnotTo, G., L'«aequitas canonica». Studio e analisi del concetto negli scritti di Enrico da Susa (Cardinal Ostiense), Editrice Pontificia Università Gregoriana, Roma 1999.

Bucci, O., Per una storia dell'equità, Apollinaris 63 (1990) 257-317.

—, «Utrumque ius»: le ragioni del diritto nella storia della Chiesa, Institutum Theologicum Franciscanum, Roma 2002, 13-20.

Calasso, F., Introduzione al Diritto comune, Giuffrè, Milano 1970.

CARon, P. G., «Aequitas» romana, «Misericordia» patristica ed «Epicheia» aristotelica nella dottrina dell'«Aequitas» canonica (dalle origini al rinascimento), Dott. A. Giuffrè, Milano 1971.

Ciulei, G., L'équité chez Cicéron, Adolf M. Hakkert, Amsterdam 1972.

Colombo, G. M., Sapiens aequitas. L'equità nella riflessione canonistica tra i due codici, Pontificia Università Gregoriana, Roma 2003.

Condorelli, O., Carità e Diritto agli albori della scienza giuridica medievale, en J. MiÑAmbres (a cura di), Diritto canonico e servizio della carità, Giuffrè, Milano 2008, 41-103.

CorTese, E., «Legistas», en DGDC V, 38-47.

CuYás, M., La buena fe en la prescripción extintiva de deudas. Desde el Concilio IV de Letrán (1215) basta Bartolo († 1357), Libreria Editrice dell'Università Gregoriana, Roma 1962. 
Fedele, P., Nibil aliud est aequitas quam Deus, en AA.Vv., Études d'bistoire du Droit Canonique dédiées à Gabriel Le Bras, I, Sirey, París 1965, 73-87.

—, Aequitas canonica, Apollinaris 51 (1978) 415-439.

FitTING, H., Juristische Schriften des früheren Mittelalters: aus Handscbriften, meist zum ersten Mal herausgegeben und erörtert, Buchhandlung des Waisenhauses, Halle 1876.

Frosini, V., L'equità nella teoria generale del Diritto, en AA.Vv., L'equità, Centro Studi giuridici «Michele de Pietro», Giuffrè, Lecce 1975, 3-16.

GaUdEMET, J., Tradition romaine et reflexion chretienne: Le concept d'«aequitas» au IVe siecle, Apollinaris 63 (1990) 191-204.

Granados, C., Misericordia y alianza en Ex 34,6-7, Scripta Theologica 48/1 (2016) 99-111.

Guarino, A., «Equità. Diritto romano», en Novissimo Digesto Italiano, VI, Unione tipografico-editrice torinese, Torino 1960, 619-624.

GuZMán Brito, A., Ratio scripta, Klostermann, Frankfurt am Main 1981.

—, La bistoria dogmática de las normas sobre interpretación recibidas por el Código civil de Chile, en AA.VV., Interpretación, integración y razonamiento jurídicos, Universidad Jurídica de Chile, Santiago de Chile 1992, 41-87.

Kantorowicz, H. - BucKLand, W. W., Studies in the glossators of the Roman law. Newly discovered writings of the 12th century, Scientia Verlag, Aalen 1969 [1938].

Kretzschmar, R., Alger von Lüttichs Traktat «De misericordia et iustitia». Ein kanonistischer Konkordanzversuch aus der Zeit des Investitursterits, Jan Thorbecke, Sigmaringen 1985.

LEFEBVRE, Ch., Les pouvoirs du juge en droit canonique. Contribution historique et doctrinale à l'étude du canon 20 sur la méthode et les sources en droit positif, Sirey, París 1938.

—, Théorie des preuves et équité canonique, Ephemerides iuris canonici 2 (1946) 282-312.

—, La doctrine de l'Hostiensis sur la préférence à assurer en droit aux intérêts spirituels, Ephemerides iuris canonici 8 (1952) 22-44.

—, «Aequitas canonica» et «periculum animae» dans la doctrine de l'Hostiensis, Ephemerides iuris canonici 8 (1952) 305-321.

MARTINI, R., «Aequitas» nell'editto del Pretore, Apollinaris 63 (1990) 241-254.

MeIJERS, E. M., L'Histoire des principes fondamentaux du droit International Privé a partir du Moyen Age spécialement dans l'Europe Occidentale, Académie de Droit International. Recueil des Cours 49 (1934/III) 543-681. 
MuÑoz, R., Fusticia y misericordia. Culpa, punición y perdón, Scripta Theologica 48/1 (2016) 131-148.

-, Le conflit entre l'équité et la loi chez les premiers glossateurs, en R. FEENSTRA H. F. W. FIsCHER (eds.), Etudes d'bistoire du droit, IV, Universitaire pers Leiden, Leyde 1966, 142-156.

Robleda, O., La «aequitas» en Aristóteles, Cicerón, Santo Tomás y Suárez, Miscelánea Comillas 15 (1951) 239-279.

—, L'equità in diritto romano, Apollinaris 51 (1978) 404-414.

Urrutia, F. J., Aequitas canonica, Apollinaris 63 (1990) 205-239.

Uscatescu Barrón, J., Acerca de un concepto romano: aequitas. Un estudio bistórico-conceptual, Cuadernos de Filología Clásica. Estudios latinos, Universidad Complutense 5 (1993) 73-104.

VALLET DE GOYTISOLO, J. B., El razonamiento jurídico: la analogía y la equidad, Real Academia de Jurisprudencia y Legislación, Madrid 1997.

Van Hove, A., De legibus ecclesiasticis, H. Dessain, Mechliniae-Romae 1930.

VIEJO-XIMÉNEZ, J. M., «Algerio de Lieja», en DGDC I, 290-293. 
